\title{
The patent deadlock
}

Citation for published version (APA):

Mulder, C. A. M. (2018). The patent deadlock: The never-ending story of patent harmonisation. Helze BV Publisher. https://doi.org/10.26481/spe.20180518cm

Document status and date:

Published: 18/05/2018

DOI:

$10.26481 /$ spe. $20180518 \mathrm{~cm}$

Document Version:

Publisher's PDF, also known as Version of record

\section{Please check the document version of this publication:}

- A submitted manuscript is the version of the article upon submission and before peer-review. There can be important differences between the submitted version and the official published version of record.

People interested in the research are advised to contact the author for the final version of the publication, or visit the DOI to the publisher's website.

- The final author version and the galley proof are versions of the publication after peer review.

- The final published version features the final layout of the paper including the volume, issue and page numbers.

Link to publication

\footnotetext{
General rights rights.

- You may freely distribute the URL identifying the publication in the public portal. please follow below link for the End User Agreement:

www.umlib.nl/taverne-license

Take down policy

If you believe that this document breaches copyright please contact us at:

repository@maastrichtuniversity.nl

providing details and we will investigate your claim.
}

Copyright and moral rights for the publications made accessible in the public portal are retained by the authors and/or other copyright owners and it is a condition of accessing publications that users recognise and abide by the legal requirements associated with these

- Users may download and print one copy of any publication from the public portal for the purpose of private study or research.

- You may not further distribute the material or use it for any profit-making activity or commercial gain

If the publication is distributed under the terms of Article $25 \mathrm{fa}$ of the Dutch Copyright Act, indicated by the "Taverne" license above, 


\section{The Patent Deadlock}

The Never-Ending Story of Patent Harmonisation

Prof. dr. dr. C.A.M. Mulder

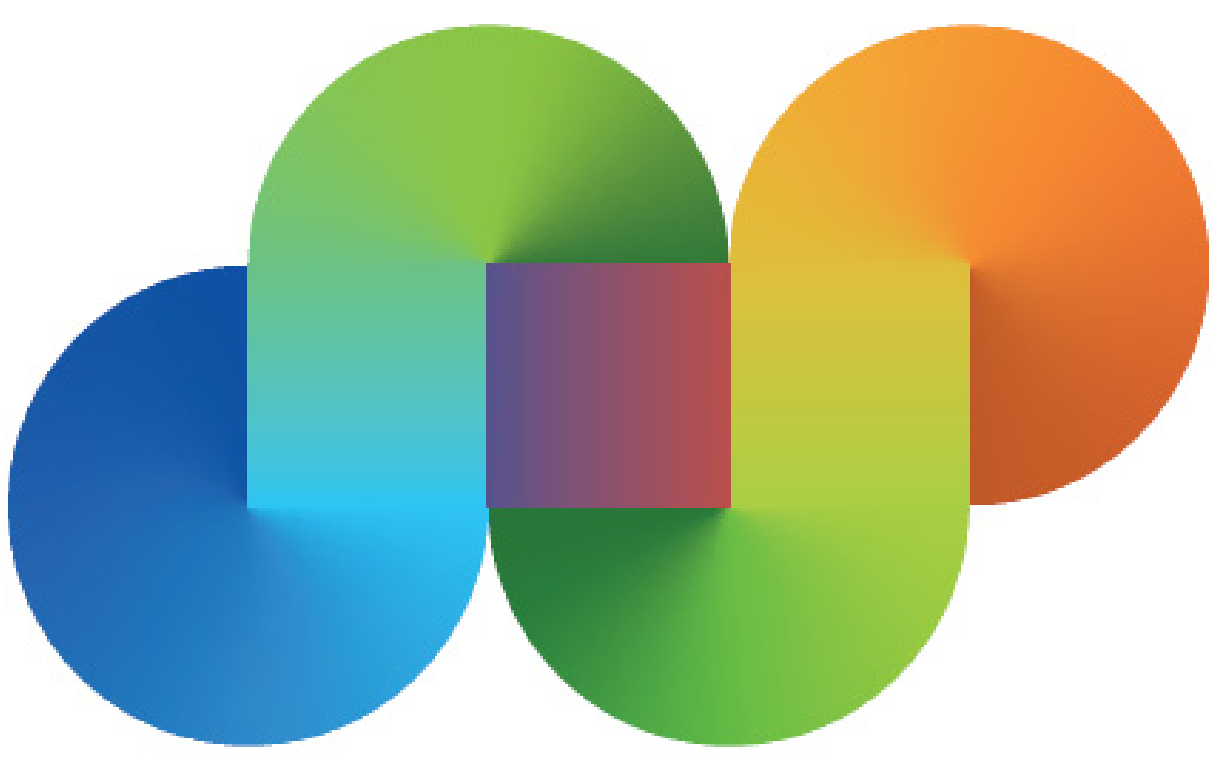





\section{The Patent Deadlock - \\ The NeVer-Ending Story of Patent HARMONISATION}




\section{(C) 2018 Cees Mulder}

\section{Helze BV, Publisher}

Emmasingel 31-141

5611 AZ Eindhoven

The Netherlands

E: helze@helze.com

www.helze.com

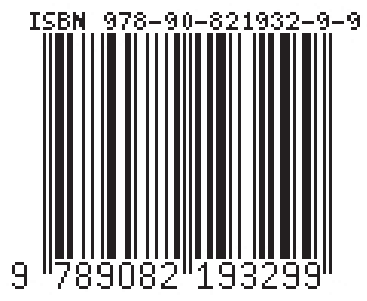

Graphic design by Volle-Kracht - Eindhoven (www.volle-kracht.nl)

Printed by Reprografisch Centrum Groningen (www.rcg.nl) 


\title{
The patent deadlock - the never-ending story of patent harmonisation
}

\author{
Rede \\ Uitgesproken (in verkorte vorm) ter gelegenheid van de aanvaarding van \\ het ambt van bijzonder hoogleraar European Patent Law in a Global Context \\ aan de Faculteit der Rechtsgeleerdheid van de Universiteit Maastricht
}

Maastricht, 18 mei 2018

Prof. dr. dr. C.A.M. Mulder 


\section{Table of Contents}

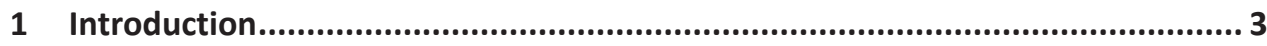

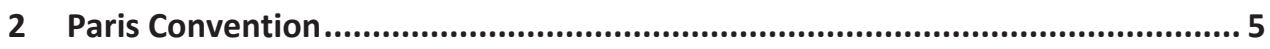

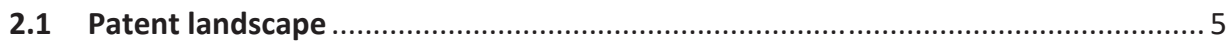

2.2 Why is patent harmonisation desirable? .................................................... 6

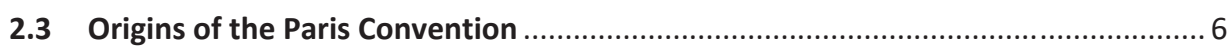

2.4 Paris Convention for the Protection of Industrial Property (1883) ....................... 7

2.5 What does the Paris Convention harmonise? ................................................. 8

2.6 What does the Paris Convention not harmonise? ............................................. 10

3 How did patent harmonisation progress after the Paris Convention? ............... 13

3.1 Strasbourg Convention on the Unification of Certain Points of Substantive Law on

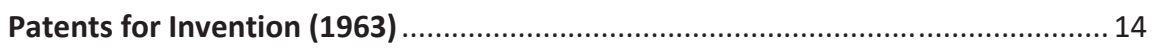

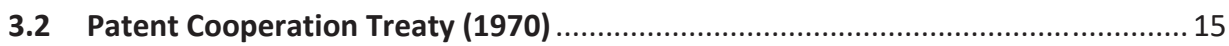

3.3 European Patent Convention $(1973 ;$ 2000) .................................................. 19

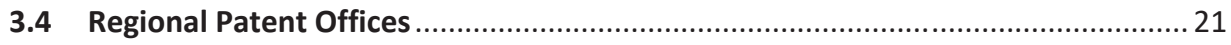

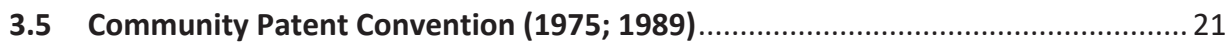

4 Successors of the Paris Convention ..................................................... 23

4.1 Draft Treaty Supplementing the Paris Convention as far as Patents are Concerned (1991) ............................................................................................ 23

4.2 Agreement on Trade-Related Aspects of Intellectual Property Rights (1995)....... 25

5 Further attempts to harmonise patent laws ............................................ 29

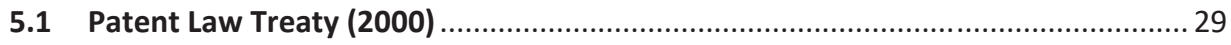

5.2 Substantive Patent Law Treaty ................................................................... 30

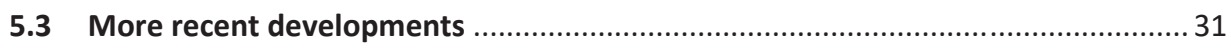

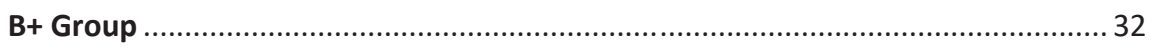

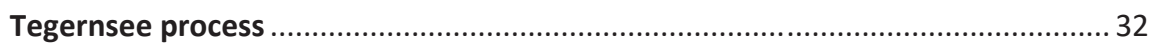

Patent Prosecution Highway................................................................ 33

European patent with unitary effect ....................................................... 34

6 Conclusion and outlook....................................................................... 37

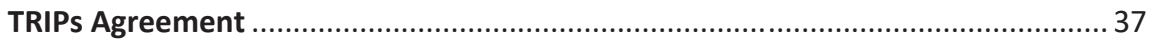

Substantive Patent Law Treaty .............................................................. 38

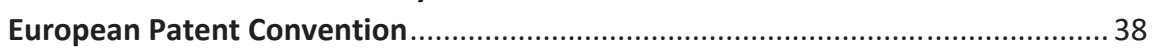

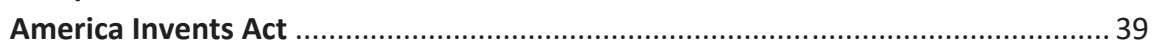

European patent system in a deadlock ................................................. 39

7 Closing remarks ............................................................................... 43

References .......................................................................................... 47 
Mevrouw de rector magnificus,

Decaan van de Faculteit der Rechtsgeleerdheid,

Gewaardeerde collega's,

Beste familie en vrienden,

Geachte toehoorders,

In principe zou ik mijn oratie graag in het Nederlands houden. Maar zelfs voor mij als Nederlander is het moeilijk om in het Nederlands over octrooien en octrooiwetten te praten, omdat de internationale taal van octrooien toch eigenlijk Engels is. Recent heb ik voor een Nederlands tijdschrift een noot geschreven bij een uitspraak van de Grote Kamer van beroep van het Europees Octrooibureau en daarbij heb ik vooral geworsteld hoe alle specifieke Engelstalige termen die mij zo vertrouwd zijn in het dagelijks gebruik, om te zetten naar 'correct' Nederlands. En dan bedoel ik niet wat is de 'letterlijke' vertaling van deze termen, maar wat zijn de overeenkomstige juridische woorden die de Nederlandse Octrooiwet en de geautoriseerde Nederlandse vertaling van het Europees Octrooiverdrag voor die begrippen hanteren. Bij wijze van voorbeeld: de officiële vertaling van het woord 'subject-matter' is 'onderwerp'. Volgens mij kun je het woord 'onderwerp' alleen gebruiken als je er meteen bij vertelt dat het iets te maken heeft met de uitvinding of het octrooi waarop het 'onderwerp' betrekking heeft.

Daarom zal ik mijn oratie in het Engels houden.

Dear all, I just explained why my inaugural lecture will be in English. 


\section{Introduction}

As you probably know, I am not a lawyer. In the nineteen-seventies, I studied physics and chemistry at the University of Utrecht and, later on, I wrote a PhD thesis at the University of Leiden on magnetic phenomena at lowtemperatures, which I defended on 18 May $1982,{ }^{1}$ which today is exactly 36 years ago.

In The Big Bang Theory, ${ }^{2}$ a famous American television sitcom, there are some physicists who, in their nerdy and for non-scientists incomprehensible manner, sometimes discuss things which come close to the topic of my old thesis. So, perhaps, what I tell you now as an introduction is not completely ununderstandable.

During the following explanation, I will show you a few pages of my $1982 \mathrm{PhD}$ thesis.

In fact, this thesis was more or less on the same topic as today: but at that time not on patent law, but on the harmonisation of spin-wave theories. I am only going to say that spin-wave theory has been successfully employed in the description of long-range magnetically ordered phases. ${ }^{3}$ Spin-wave theory could be applied to the crystals I was conducting magnetisation experiments on at that time in superfluid helium, which is around minus 270 degrees Celsius. The theoretical results from the model could be used to explain and better understand the experimental results.

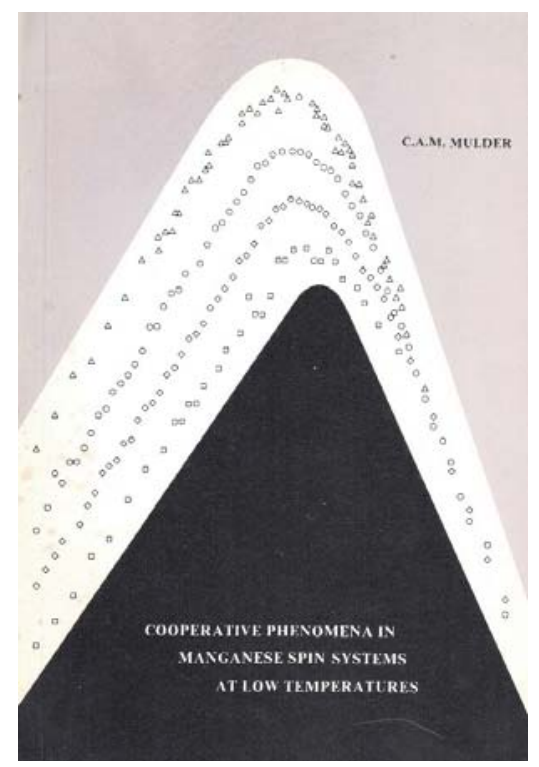

Before starting to do research in Leiden, I had worked as an MSc student in the Department of Solid State Physics under the guidance of a Professor in Utrecht. $\mathrm{He}$ and his $\mathrm{PhD}$ candidates had for several years published experimental results 
of magnetisation experiments on various types of crystals. In each of these articles, a portion of the spin-wave theory for that specific crystal was derived.

As part of my research In Leiden, I tried to find a formulation of spin-wave theory that would encompass all these specific cases and also other cases described in literature. In two comprehensive articles, I derived, together with a Professor of theoretical physics, a systematic treatment of two-dimensional magnetically-ordered crystals. ${ }^{4-5}$ The resulting model was so general, that the cases that had been published in the literature could be regarded as special cases of the theory.

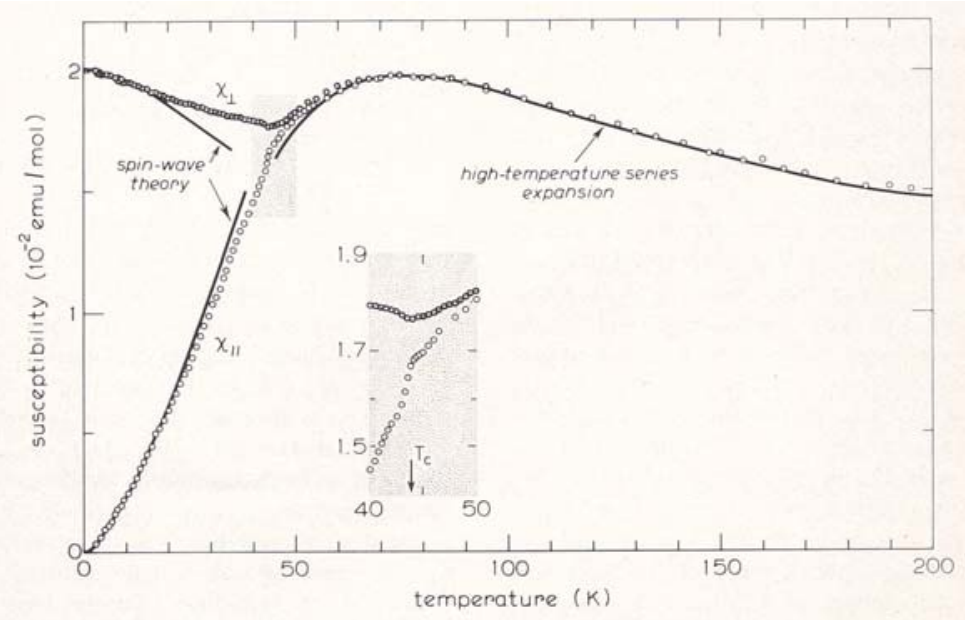

Fig. 2. The differential susceptibility of a single crystal of $\mathrm{K}_{2} \mathrm{MnF}_{4}$ as a function of temperature in zero static external magnetic field. The oscillating field $(\sim 2.5 \mathrm{Oe}, 117 \mathrm{~Hz})$ is applied either parallel (open circles) or perpendicular (shaded circles) to the preferential axis ( $c$ axis) of the crystal. The full curves represent best fits to renormalized spin-wave theory or to the high-temperature series expansion.

In fact, I had harmonised spin-wave theory for certain classes of crystals. The theory also predicted certain properties of crystals, which were confirmed when the corresponding experiments were done. ${ }^{6}$

The Professor in Utrecht did not want to come to the defence of my thesis in Leiden.

So, now let's turn to patent law. 


\section{Paris Convention}

When did patent harmonisation start? Well it started with the Paris Convention for the Protection of Industrial Property which was adopted in 1883, that is 135 years ago.

However, let me first briefly describe the legal framework of patenting inventions.

\subsection{Patent landscape}

Patents are only granted for technical inventions. To keep things simple: an invention is a non-obvious technical solution to a technical problem. In order to protect the invention, a patent application must be filed at the central industrial property patent office of a country, where it will be examined on its inventive merits which may result in the grant of a patent.

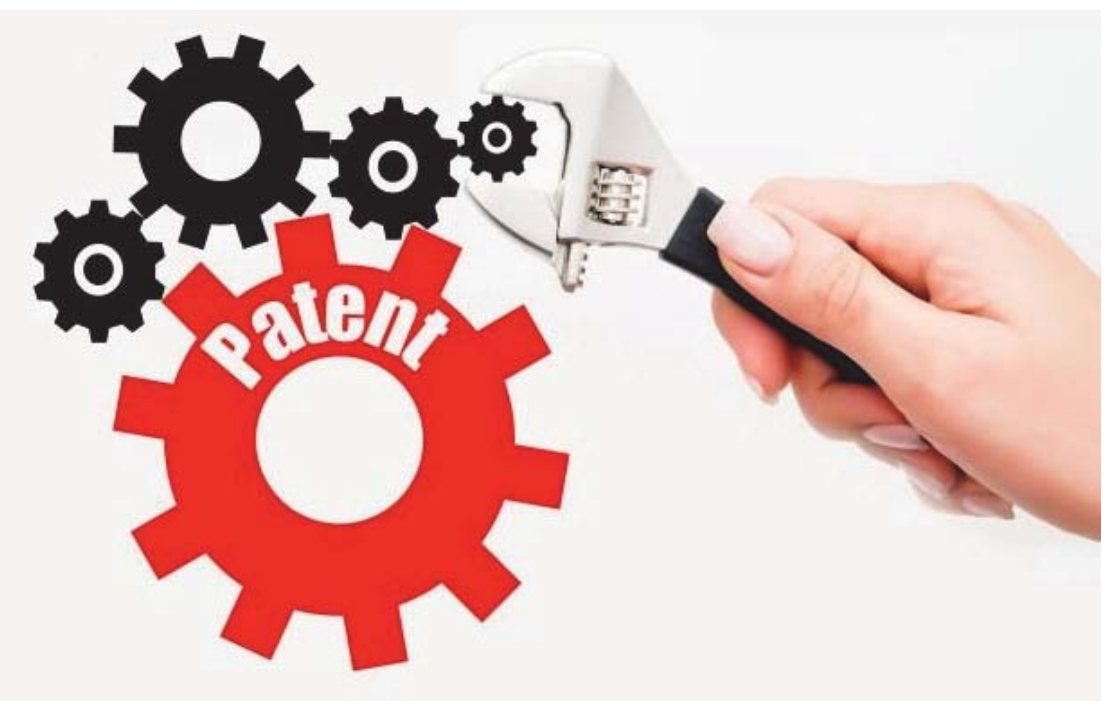

In principle, a patent right is a territorial right: the grant and enforcement of the patent are governed by the national law of the country where it is granted. In addition, the interpretation of patent claims and the extent of protection provided by the patent vary from country to country.

It is not possible to obtain a world-wide patent right for an invention. 
In patent law, the date of filing plays a vital role. The relevant literature for a patent application - also known as the 'prior art' - is everything made available before the date of filing of the application. So it is crucial to obtain the earliest filing date to ensure that the invention disclosed in the application has a better chance to be novel with respect to the prior art. Also, the invention should not be disclosed to anyone prior to filing the patent application.

It is practically not possible to file patent applications for the same invention in several countries on the same day. This implies that the prior art for these patent applications could be different depending on the filing date of the application in that specific country. In addition, the applications for the same invention filed in different countries may be in each other's way.

\subsection{Why is patent harmonisation desirable?}

Global harmonisation of patent law has many advantages. The main motivation for harmonisation is that redundancy in the prosecution of patent applications would be minimised. Harmonisation would also result in a reduction of the administrative burden in the participating States. As a consequence, the costs of the granting process and the maintenance of patents after grant would be largely reduced. In addition, litigation of patents before a unified patent court would also reduce the costs. Patent owners would benefit from these reductions.

\subsection{Origins of the Paris Convention}

In 1873, an international exhibition was held in Vienna, at that time the capital of the Austro-Hungarian Empire.

As inventors were unwilling to exhibit their inventions, a special law was passed securing temporary protection to exhibitors. The result was a so-called 'période de grâce' or 'grace period'. The inventor could present his invention at the exhibition and was, under certain conditions, allowed to file a patent application later on for which his own disclosure would not be taken into account as prior art. 
This Congress of Vienna for Patent Reform led to an International Congress on Industrial Property which was convened in Paris.

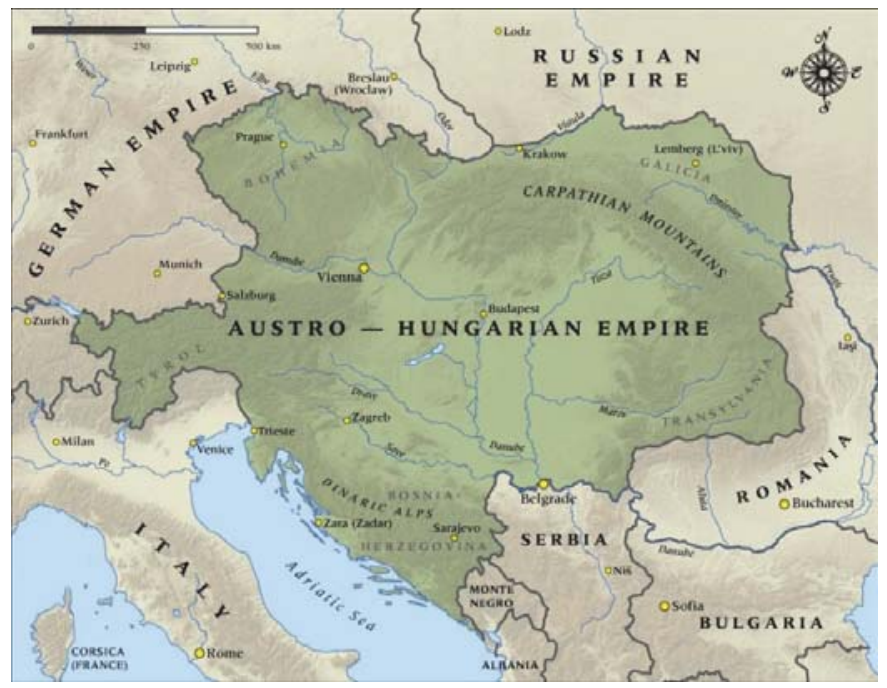

\subsection{Paris Convention for the Protection of Industrial Property (1883)}

The Paris Convention for the Protection of Industrial Property was signed by 11 States in 1883 - including The Netherlands. Among others, the Convention puts forward a solution to the problem with different dates of filing.

Today, the Paris Convention encompasses more than 175 member States which is $90 \%$ of the number of countries worldwide. ${ }^{7}$

The International Bureau of the World Intellectual Property Organization ${ }^{8}$ (WIPO) administers the Paris Convention, but the Bureau has not been given competence to interpret the Convention. However, there is an excellent book about the Paris Convention written in 1968 by the Dutch civil servant George Bodenhausen, who at that time was director of the

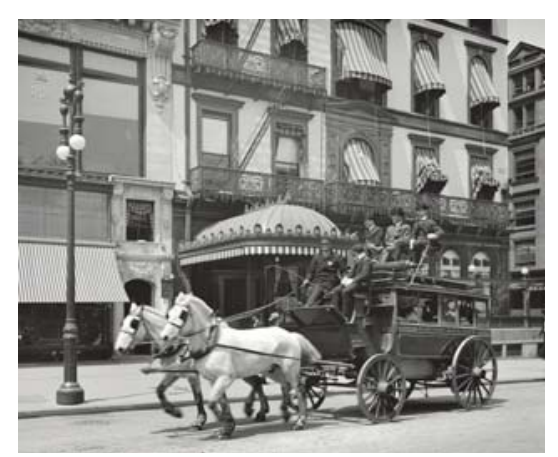
Organization. ${ }^{9-10}$ 


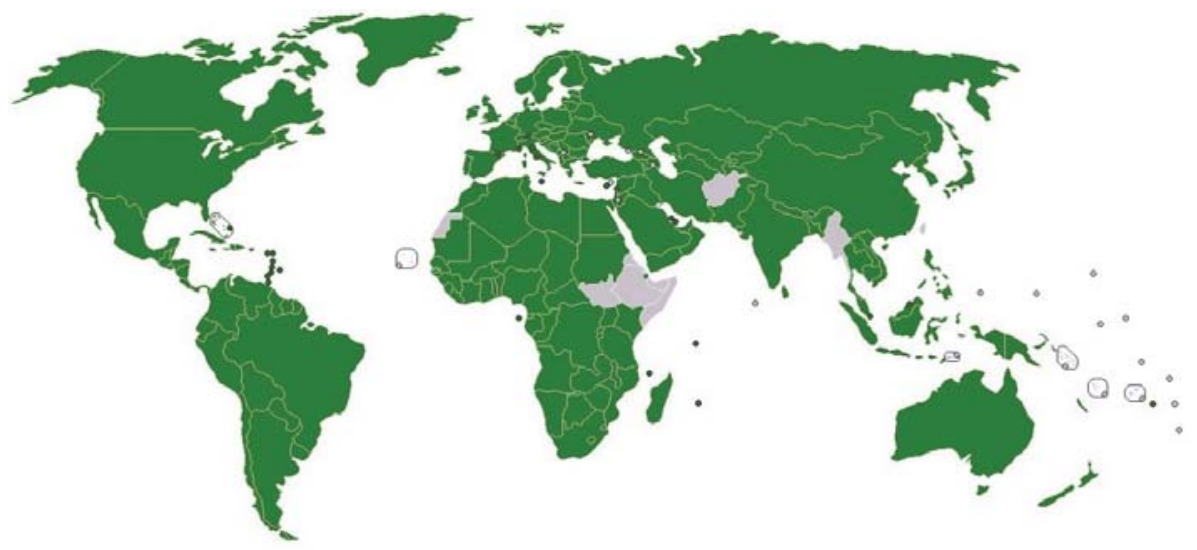

Paris Convention - 177 member countries

Apart from patents for inventions, the Paris Convention also addresses trademarks and unfair competition, as well as the related industrial property of industrial designs, utility models, geographical indications, trade names but not copyright. In view of the topic of today, my lecture will focus on patents for inventions.
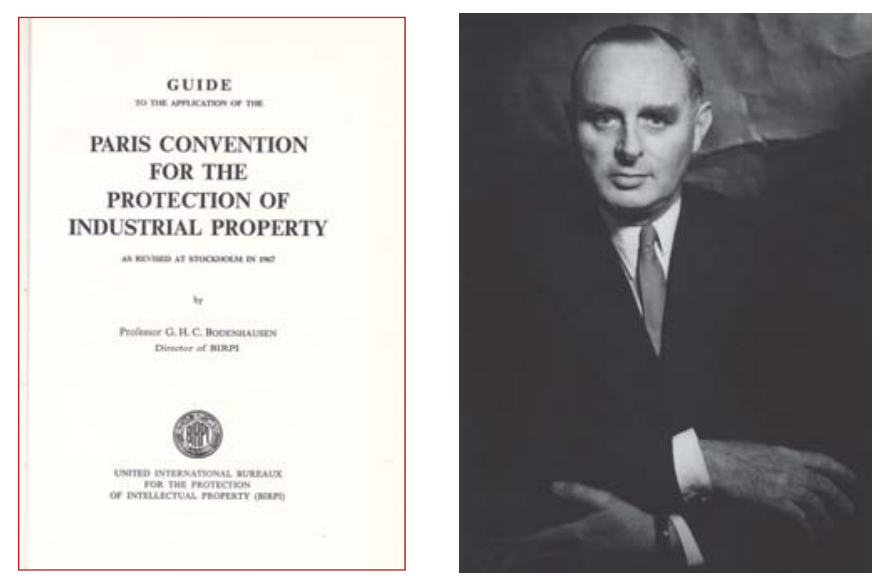

\subsection{What does the Paris Convention harmonise?}

One of the substantive requirements in relation to the protection of industrial property in the Paris Convention is the principle of "national treatment", which governs that each Contracting State must grant the same protection to nationals of other Contracting States that it grants to its own nationals. ${ }^{11}$ The 
same applies to nationals of non-Contracting States who are resident in a Contracting State. ${ }^{12}$

One of the most important elements of the Paris Convention is the 'right of priority' which was already included in the original 1883 text. ${ }^{13}$ It allows an applicant to file a first application at a certain date in one State, for instance in his home country, and to file later a subsequent application or a plurality of subsequent applications while benefiting from the date of filing of the earlier application. The advantage is that an inventor no longer is compelled to file his patent applications in all countries on the same day.

This 'first application' is also referred to as the 'priority application', whereas its date of filing is called the 'priority date'. The 'effective date' of the later application is not the date of filing of that application, but the filing date of the earlier application. This priority date is considered to be the 'effective date' for examining the patentability requirements of the subsequent application. In other words, the prior art which is taken into account for examining novelty and inventive step of the invention claimed in the subsequent application, would be everything made available to the public before the filing date of the priority application.

Of course, the priority principle only works for 'countries of the Union', which is a stimulus to become a party to the Paris Convention. An additional and understandable requirement is that the right to priority is only effective if the subject matter of the priority application and the later applications are substantially the same. ${ }^{14-15}$

The right of priority may be invoked by a successor in title of the applicant. ${ }^{16}$ In addition, the right of priority may be transferred to a successor in title independently of the transfer of the first application on which it is based.

The harmonised period of priority is twelve months for patents and utility models. A utility model is a kind of small patent. ${ }^{17-18}$ 
The Paris Convention also harmonises a number of substantive issues in relation to the protection of patents: ${ }^{19}$

o the principle of independence of patents obtained for the same invention in different countries; ${ }^{20}$

o the term of a patent is to be measured in accordance with the applicable national law without being shortened by the priority period; 21

o the right of the inventor to be mentioned in the patent; ${ }^{22}$

o patentability is not restricted by restrictions on the product; ${ }^{23}$

o the importation of patented products or products made from patented processes does not entail forfeiture of the patent; ${ }^{24}$

o the failure to work of an invention and the provision of compulsory licenses; ${ }^{25}$

○ a grace period for maintenance fees; ${ }^{26}$

and last but not least, of course,

- a temporary protection for inventions shown at an International Exhibition. ${ }^{27}$

\subsection{What does the Paris Convention not harmonise?}

In his book, Bodenhausen already raised the question whether the provisions of the Paris Convention in relation to substantive law are 'self-executing' or not. $^{28}$ The conclusion was that the provisions in relation to these issues in the Paris Convention as an international convention are drafted in such a manner that they should directly apply in countries with a constitution or constitutional system that permits provisions of an international convention to be 'selfexecuting' ${ }^{29}$

In the field of patents for inventions, the Paris Convention leaves the member States entirely free:

o to establish the criteria for patentability;

o to decide whether patent applications should or should not be examined in order to determine, before a patent is granted, whether these patentability criteria have been met; 
○ whether the patent should be granted to the first inventor or to the first applicant for a patent;

o whether patents should be granted for products only, for processes only, or for both; and in which fields of industry; and

o what the term of the patent is.

More importantly, the Paris Convention is not concerned with the enforcement of patents. The extent of protection of a patent is limited to the territory of the State that grants it - or for which it is granted - and the Paris Convention does not provide a mechanism to implement enforcement outside the territorial boundary of a Contracting State. ${ }^{30}$ 


\section{How did patent harmonisation progress after the Paris Convention?}

We have to realize what a breakthrough the Paris Convention was at that time and still is today. It has simplified a number of things and the Contracting States agreed to uphold these issues.

At the time of discussing the Paris Convention, there were also hopes that a new treaty could be concluded that would create a world-wide patent.

However, for many years there were no new developments. In the first half of the twentieth century, the world was immersed in two world wars of which the first one, the Great War, also resulted in the dissolution of the AustroHungarian Empire.

After the Second World War, the pressure for further harmonisation increased. Due to the continuous advancement of industrialisation, applicants were filing their patent applications in more countries. The patent offices of certain countries could no longer digest the increasing numbers of patent applications filed. One of the solutions was to come to regional patent offices. However, agreement on substantive aspects of patentability, such as novelty and inventive step, did not show much progress. 


\subsection{Strasbourg Convention on the Unification of Certain Points of Substantive Law on Patents for Invention (1963)}

In 1963, the Convention on the Unification of Certain Points of Substantive Law on Patents for Invention was concluded. This multilateral Treaty, which is commonly known as the Strasbourg Convention, attempts to harmonise substantive patentability criteria.

The Strasbourg Convention was signed in 1963 by Member States of the Council of Europe. ${ }^{31}$ After ratification by 8 Member States, it entered into force on 1 August 1980. ${ }^{32}$ The Treaty is administered by the Council of Europe.

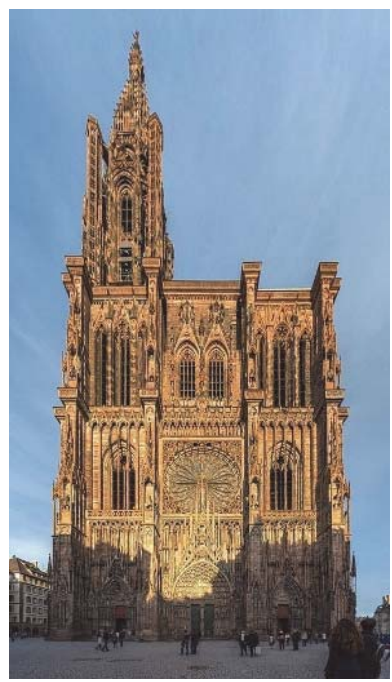

Among others, the Strasbourg Convention:

- specifies that certain types of inventions can be rejected as being not patentable; ${ }^{33}$

- defines topics such as novelty and inventive step in relation to the prior art; $^{34}$

○ states that the description of the patent application should disclose the invention in a manner sufficiently clear and complete for it to be carried out by a person skilled in the art; ${ }^{35}$ and

o sets boundaries to the extent of protection conferred by the patent. ${ }^{36}$

Although the Strasbourg Convention is often referred to as the 'forgotten convention', it has led to a significant harmonisation of patent laws across European countries. ${ }^{37}$ The text of the articles of the Strasbourg Convention has more or less literally been incorporated in the European Patent Convention. ${ }^{38}$ In so far as relevant, this also occurred in the Patent Cooperation Treaty. ${ }^{39}$ These treaties will be discussed now. 


\subsection{Patent Cooperation Treaty (1970)}

In the book "The first twenty-five years of the Patent Cooperation Treaty (1977-1995)", Arpad Bogsch, who was General Director of WIPO from 1973 to 1997, describes that the whole patent system in the midnineteen sixties was 'in crisis'. ${ }^{40}$ The number of patent applications filed was: ${ }^{41}$

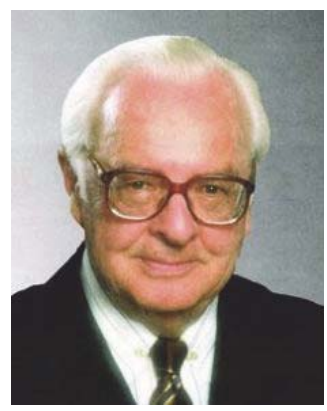

"so high that examination backlogs grew alarmingly and pendencies were so long that by the time a decision was made by the patent office on whether or not to grant a patent, the applicant's economic interests in the invention had faded."

In the second half of the 1960s, plans progressed to come to a world-wide patent treaty which allowed applicants to file one 'international application' in one language, instead of filing separate patent applications at national patent offices, with each office prescribing its own language of filing.

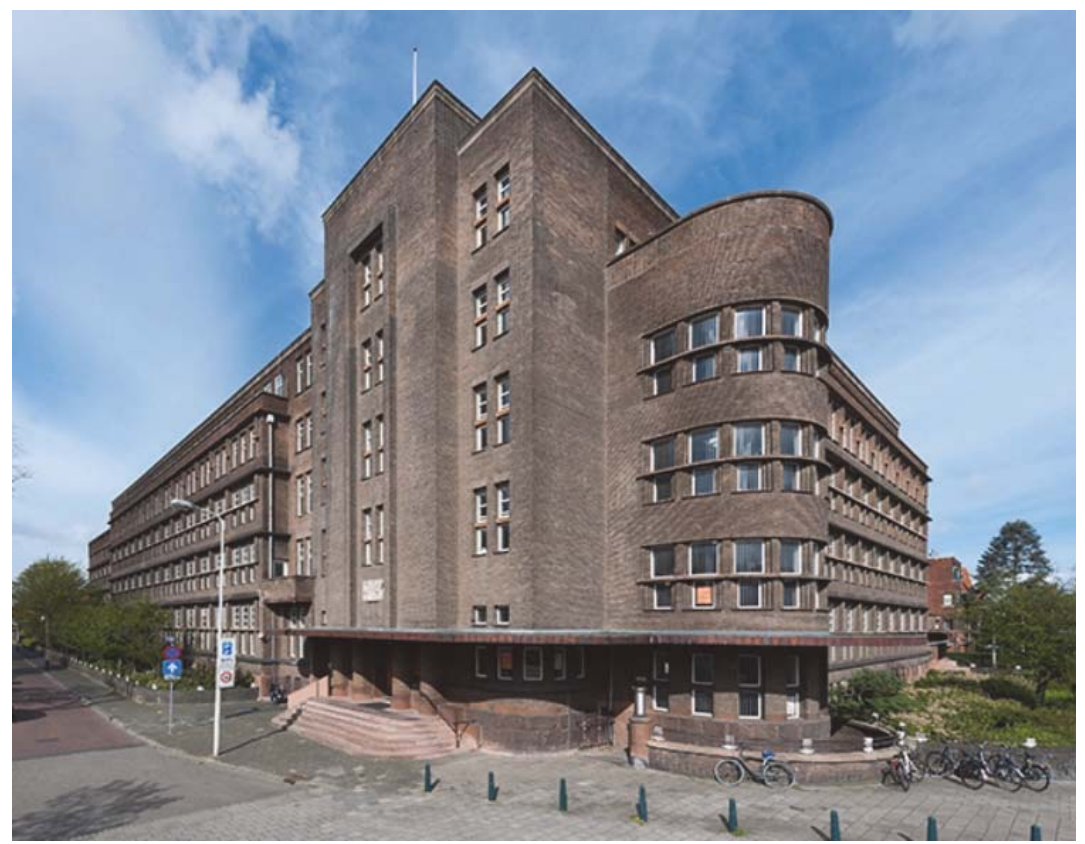

Institut International des Brevets (The Hague) 
There would be one international search to be performed by the "Institut International des Brevets" (IIB) which was established in The Hague in 1947.42-43 This institute later on became an integral part of the European Patent Organisation, the so-called 'branch' of the European Patent Office (EPO) in a suburb of The Hague. ${ }^{44}$ As you know, important institutions of the EPO are often located in suburbs. ${ }^{45}$

Having only one International Searching Authority (ISA) was not realisable. For political, economic and language reasons, we today have 22 international authorities performing international searches. ${ }^{46}$ In addition, the PCT has 10 languages of publication. ${ }^{47}$

The PCT does not grant patents. A major drawback of the PCT is that most national and regional patent offices do not regard the result of the international search as sufficient for the national or regional examination of the international application. Hence, most patent offices perform a supplementary search and base the substantive examination on the outcome of this search. This means that applicants upon entry have to pay another search fee. This defies the aim of harmonisation advocated by the PCT.

The Patent Cooperation Treaty (PCT) was adopted and signed on 19 June 1970 in Washington. It entered into force in January 1978, initially with 18 Contracting States. Any Contracting State to the Paris Convention for the Protection of Industrial Property can become a member of the PCT. ${ }^{48}$ Today, more than 150 States are party to the PCT. ${ }^{49}$

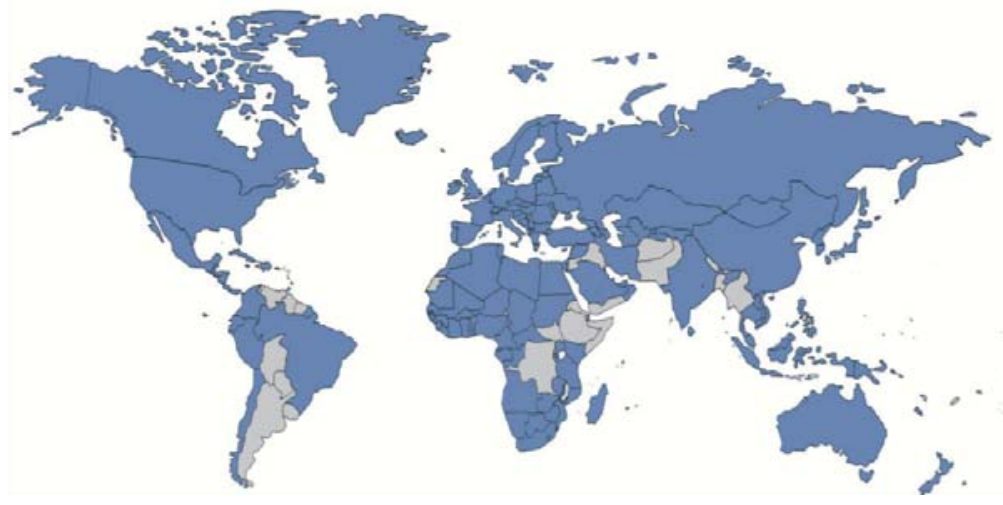

Patent Cooperation Treaty - 152 member countries 


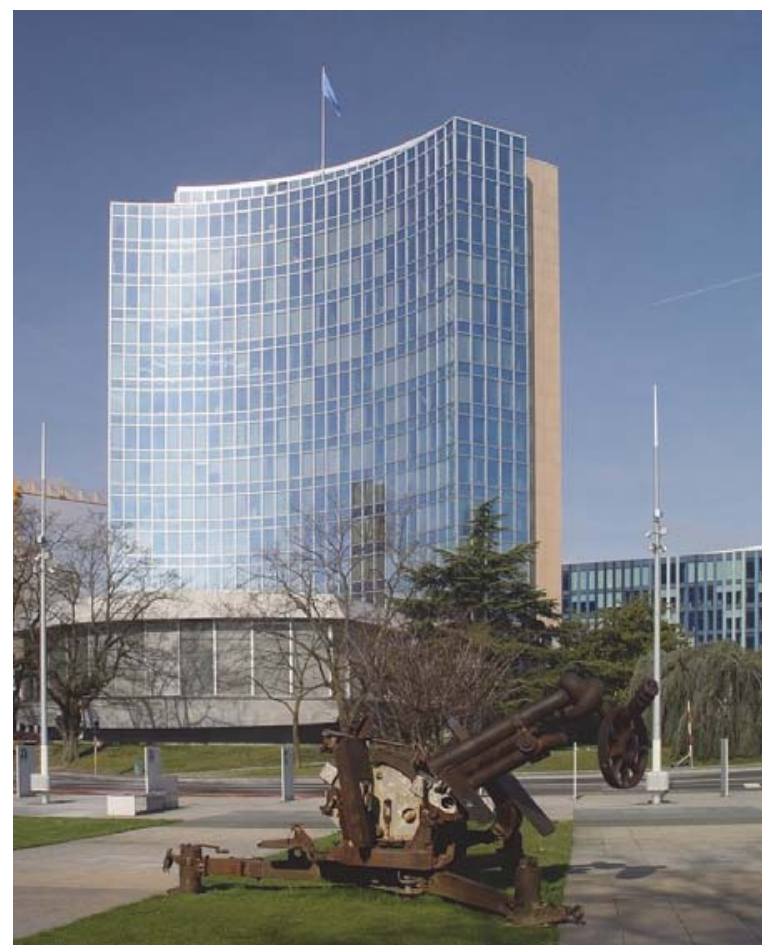

World Intellectual Property Organization (Geneva)

In 2017, more than 240,000 international applications were filed. ${ }^{50}$ In February 2017, the three millionth application was published by the International Bureau of WIPO. ${ }^{51}$

We have to realise that the Patent Cooperation Treaty (PCT) was negotiated during the Cold War. The Americans and the Russians did not trust each other. ${ }^{52}$ With respect to technology, these countries were in a Space Race. As a consequence of this mistrust the Articles of the PCT were carved in stone. Changing the Articles requires a Revision Conference, which is difficult to organise with $150+$ member countries. In addition, it is very difficult to obtain consensus with so many different opinions.

If more flexibility is required in the PCT, the Rules implementing the PCT are amended to provide more freedom. The result of all these changes throughout the years, is that the Rules often deviate or contradict the meaning of the Articles. These inconsistencies make the PCT difficult to read and understand. ${ }^{53}$ 


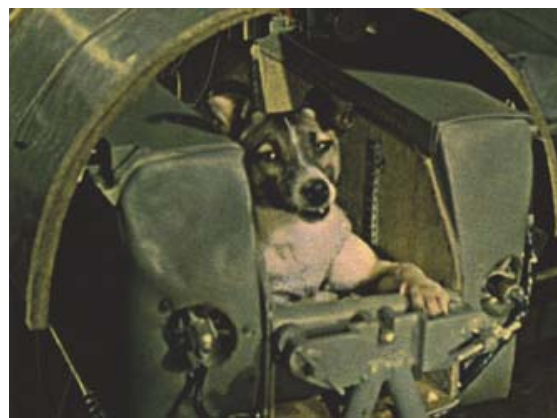

1957 - Sputnik 2 (dog Laika)

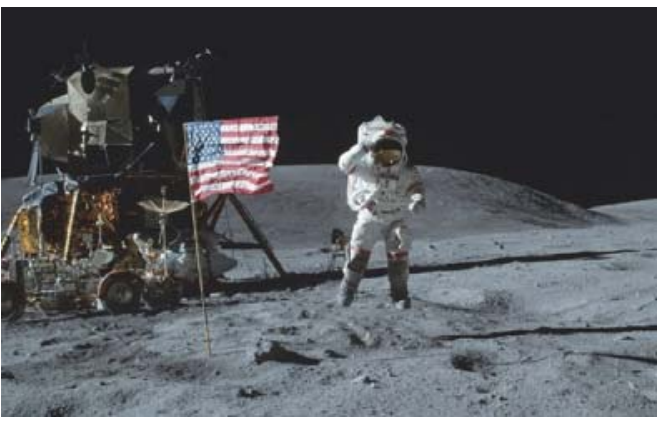

1969 - Apollo 11

International applications under the PCT are published 18 months after the filing or priority date together with - if prepared in time - the international search report. ${ }^{54}$ Around $50 \%$ of the international applications are published in English. ${ }^{55}$ If published in another language the cover page of the application and the international search report are also available in English. ${ }^{56}$

At the end of the international phase, the applicant has an 'International Preliminary Report on Patentability' of the claimed invention. ${ }^{57}$ Based on this report, the applicant can take an informed decision whether or not to seek protection for his invention by entering before national or regional patent offices. ${ }^{58}$

One of the major advantages of the PCT is that the start of the national phase is delayed by at least 30 months from the priority date of the application. ${ }^{59}$

Later on in this lecture, I will come back to the PCT.

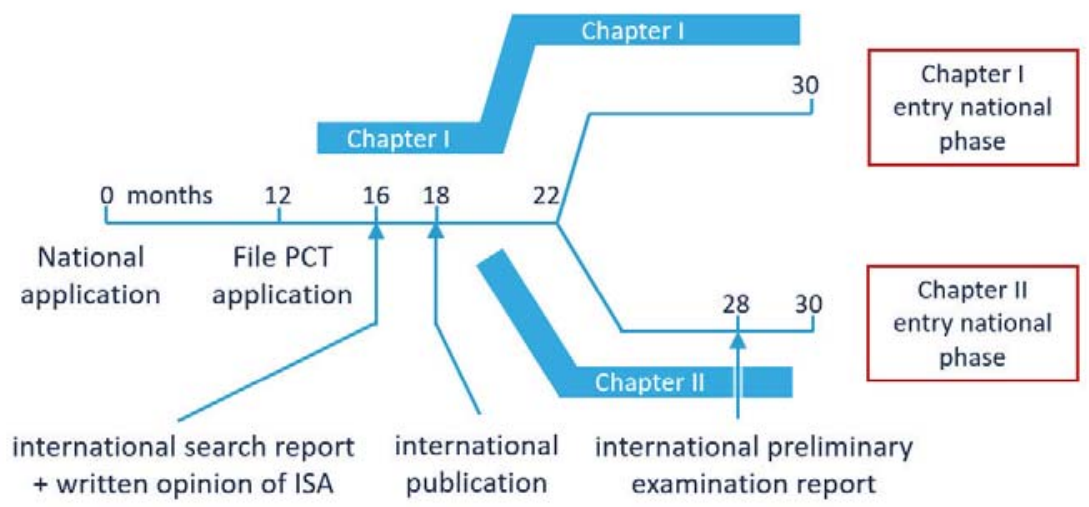




\subsection{European Patent Convention $(1973 ; 2000)$}

What happened in Europe after the second world war?

The idea in Europe was to create a community patent, which means the filing of one European patent application at a central institution, which application would then be searched, published and examined by that institution. After grant, the patent would become a single community patent with unitary effect in all the member States. Unfortunately, the latter goal turned out to be not achievable. As a compromise, it was agreed, that once a European patent application has been found grantable by the European Patent Office (EPO), it falls apart in a bundle of national patent rights for each of the designated countries. As a consequence, any infringement of a European patent is dealt with by national law. ${ }^{60}$

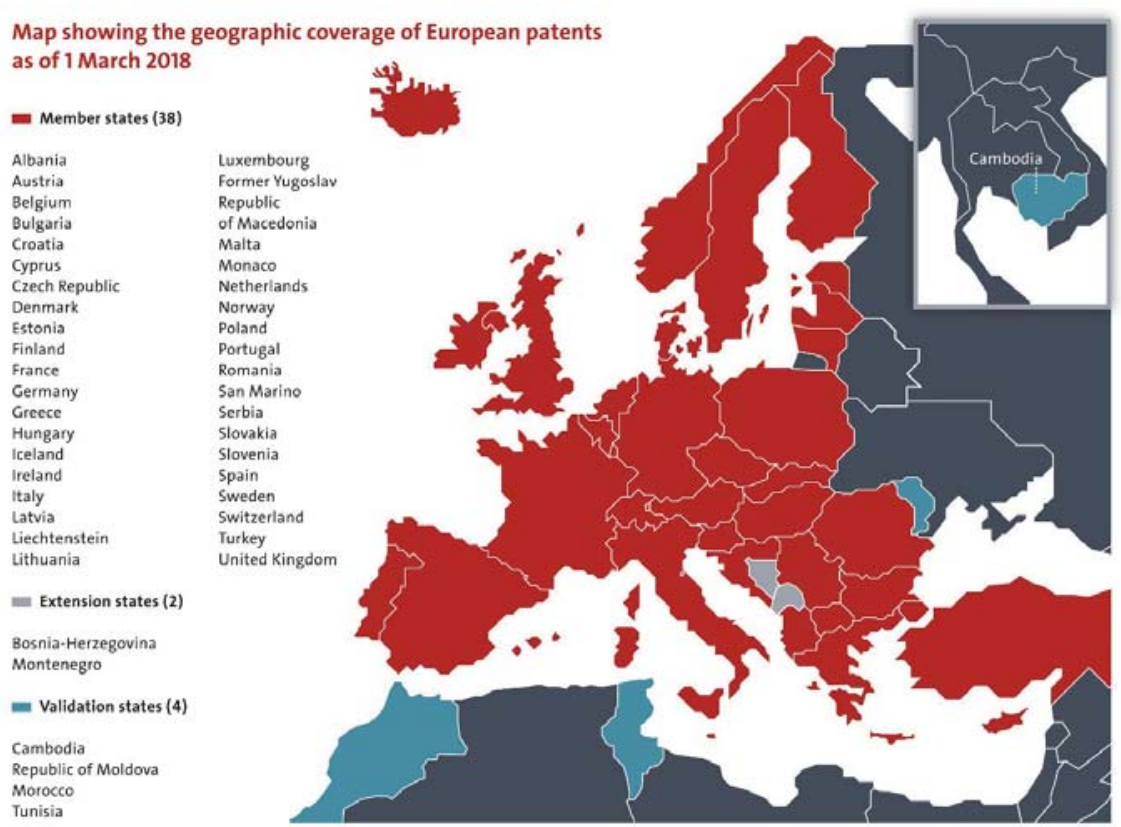

After more than 20 years of negotiations and debate, ${ }^{61} 16$ countries signed the European Patent Convention (EPC) on 5 October 1973 in Munich. When four years later the first European patent application was received by the European Patent Office, there were 8 Contracting States. Currently, the granted European 
patent can take effect in 38 States in Europe as well as for a number of socalled Extension States and Validation States within as well as outside the European continent. 62

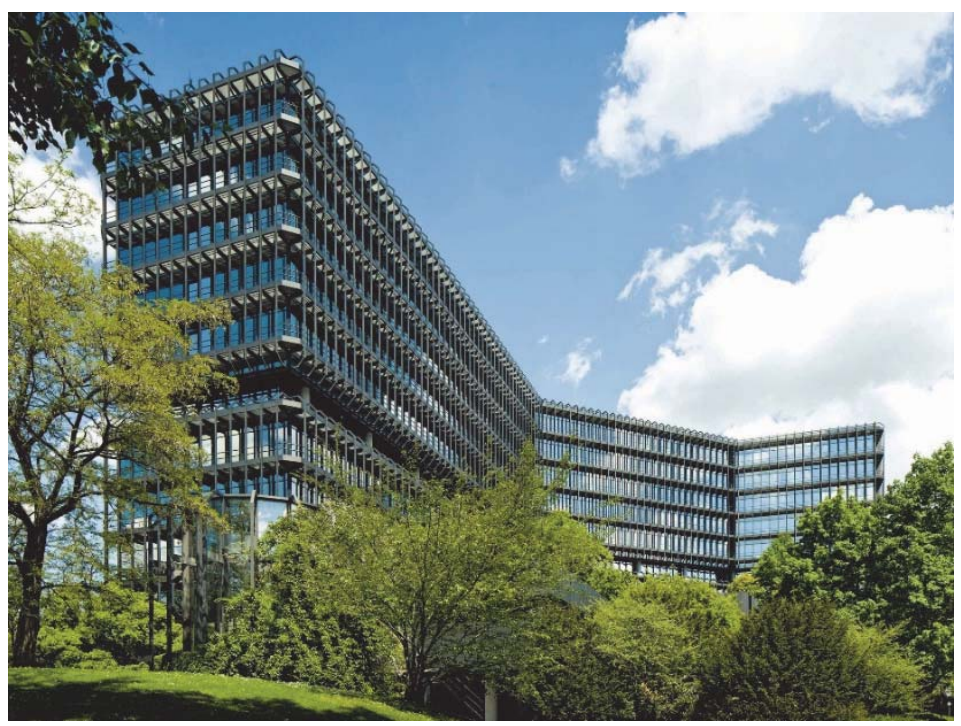

European Patent Office - Isar Building (Munich)

A Revision Conference held in Munich in November 2000, did not introduce any major changes in substantive patent law. ${ }^{63}$ A number of substantive topics, such as software and biotech inventions as well as the introduction of a grace period for inventors were postponed to the so-called 'second basket' to be dealt with in a later revision conference which never took place. ${ }^{64}$

As mentioned earlier, the substantive requirements of patentability in the European Patent Convention were largely taken over from the Strasbourg Convention. So, if you have always wondered why Art. 53 EPC has paragraphs (a) and (b) whereas Art. 54 EPC has paragraphs (1) and (2), then this is because the same paragraph indication is used in the Strasbourg Convention. ${ }^{65}$

One of the major advantages of the European Patent Convention is that there is a unified and harmonised procedure for the substantive examination of the European patent applications by the European Patent Office. The boundaries of what is prior art are firmly established by jurisprudence. ${ }^{66}$ In addition, for the 
assessment of inventive step, the so-called problem-and-solution approach was developed by the boards of appeal in the early 1980s. ${ }^{67}$ Since then, this approach is obligatory before all departments of the EPO.

Contracting States had to accommodate requirements of the EPC in their national patent laws. This stimulated, as a not-foreseen side effect, the harmonisation among national patents in the European region.

\subsection{Regional Patent Offices}

The European Patent Office is a so-called 'regional patent office'. Worldwide there are four regional patent offices. They examine patent applications which after grant take effect in the participating States cooperating for this purpose.

Regional patent organisations are: ${ }^{68}$

○ the African Regional Intellectual Property Organization (ARIPO) which covers 19 States in the eastern and southern parts of Africa - not including South Africa; ${ }^{69}$

o the African Intellectual Property Office (OAPI) which encompasses 17 French-speaking States - former colonies of France - in the western part of Africa; ${ }^{70}$

$\circ$ the Eurasian Patent Office (EAPO) covering 8 States around and including the Russian Federation; ${ }^{71}$ and

o the European Patent Office (EPO) which grants European patents for 38 States in the European region as well as for a number of Extension States and Validation States. ${ }^{72}$

The Patent Cooperation Treaty (PCT) is fully compatible with the regional patent systems. ${ }^{73}$

\subsection{Community Patent Convention $(1975 ; 1989)$}

Despite the achievement of the European Patent Convention, it was supposed to be only the first step. ${ }^{74}$ The next step was to come to a unified European patent which would - after grant - have a truly unitary character and be valid in all member States. This patent should be centrally enforceable, with the European Court of Justice at the end of the judicial chain. 
This 'next' step was supposed to be the Community Patent Convention (CPC). The Convention for the European Patent for the Common Market was concluded on 15 December 1975 in Luxembourg, but has never entered into force. The main reason for its failure was that a translation into 11 languages was compulsory.

In 1989, the CPC was amended by introducing a Common Appeal Court and a protocol in relation to the infringement and validity of the community patents. The amended Convention also never entered into force, because only seven Member States ratified it. Several later attempts to revive the Convention also failed. Agreement could not even be reached on translation requirements after the grant of the European patent.

In 2004, the CPC was finally aborted. Nevertheless, the Official Journal of the EPO in 2012 still mentioned the 12 Signatory States to the Community Patent Convention of 1989. ${ }^{75}$ And, even today, candidates preparing for the European Qualifying Examination (EQE) officially still need to have "a thorough knowledge of ... any legislation relating to Community patents" ${ }^{76}$ although questions have never been asked about it.

Fairy tales do not come true if you tell them time after time. 


\section{Successors of the Paris Convention}

The question can be asked: was there ever a successor of the Paris Convention? As we will see, the answer to this question is yes and no.

\subsection{Draft Treaty Supplementing the Paris Convention as far as Patents are Concerned (1991)}

In 1984, discussion started on a successor of the Paris Convention with focus on patents. The negotiations continued until June 1991 and resulted in a first part of a Diplomatic Conference in The Hague to conclude a "Treaty Supplementing the Paris Convention as far as Patents are Concerned". ${ }^{77}$ This Treaty is often also referred to as the "Patent Harmonisation Treaty".

The second part of the Diplomatic Conference, scheduled for July 1993, did not take place.

In January 1994, the United States discontinued the discussion on this Treaty due to a lack of domestic support. The United States did not come to Geneva to inform the International Bureau of WIPO, but the Department of Commerce of the United States of America simply issued a press release: ${ }^{78}$

\footnotetext{
"that the United States would not seek to resume negotiations of a treaty harmonising the world's patent laws at this time. While other international negotiations continue, we will maintain our first-to-invent system while keeping open the option of full patent harmonisation in the future."
}

The International Bureau was furious about the manner of communication and the international community was disappointed by the ensuing 'loss of momentum' on the topic of substantive patent law harmonisation.

And the draft Patent Harmonisation Treaty was so beautiful and complete, and would for the first time harmonise everything that industries, small and medium business enterprises, and universities, in developed and developing countries could desire. 
Among others, the Basic Proposal of the Treaty gave provisions for: ${ }^{79-80}$

○ Disclosure of the invention in the description; ${ }^{81}$

○ Contents and style of the claims; 82

○ Unity of invention; ${ }^{83}$

- Identification of the inventor and applicant and right to the patent; ${ }^{84}$

○ Belated claiming of priority; ${ }^{85}$

- Minimum requirements for accordance of a filing date, including filing by reference to another application; ${ }^{86}$

○ Fields of technology and conditions of patentability (novelty and inventive step) ${ }^{87}$

- Disclosures not affecting the patentability of the invention, including a grace period for inventors; ${ }^{88}$

○ Prior-art effect ('whole-contents approach'); ${ }^{89}$

- Amendment and correction of the application; ${ }^{90}$

- Procedural requirements for search, publication and substantive examination of the application; ${ }^{91}$

○ Limitation and revocation of the patent; ${ }^{92}$

- Correction of obvious mistakes; ${ }^{93}$

○ Rights conferred by the patent including equivalent elements and prior statements; ${ }^{94}$

○ Right of prior user; ${ }^{95}$

O Extent of protection and interpretation of claims; ${ }^{96}$

○ Term of the patent; ${ }^{97}$

○ Enforcement of rights; ${ }^{98}$

○ Reversal of the burden of proof; ${ }^{99}$

○ Remedial measures under national legislation; ${ }^{100}$

○ Role of the International Bureau; ${ }^{101}$ and

○ Settlement of disputes. ${ }^{102}$

Had this Treaty been accepted and ratified, the TRIPs Agreement would probably not have been necessary.

One important aspect to mention is that the negotiating parties had already accepted, although reluctantly, the introduction of a grace period for inventors 
as is incorporated in US patent law. ${ }^{103}$ A grace period allows an inventor to file a US patent application within a period of 12 months after disclosing his invention, whereby this disclosure does not affect the patentability of his application. Having shown their willingness to accept the grace period, ${ }^{104}$ the other countries were not prepared to accommodate the first-to-invent system into the Basic Proposal, which, together with the elaborate interference proceedings, was a strange peculiarity of US patent law.

As can be learned from the press release, the lack of incorporating the first-to-invent option was the main reason why the Americans stopped negotiating the Treaty. ${ }^{105}$

In my opinion, the Americans deliberately pulled the plug on the negotiations towards the "Patent Harmonisation Treaty", as they believed that they could play the game more effectively on another level.

To make this clear, we have to go back a little bit in time.

\subsection{Agreement on Trade-Related Aspects of Intellectual Property Rights (1995)}

In the late nineteen-seventies, American pharmaceutical companies already argued that the Paris Convention and the Patent Cooperation Treaty failed to provide adequate patent protection for their products in developing countries. In addition, they advocated that enforcement of their patents in these countries should be made more effective. ${ }^{106}$

In the early eighties, the industrialised countries tried to amend the 1883 Paris Convention to include provisions on enforcement. Eventually, the Paris Convention was not amended because of disagreement on the voting rules and the focus of developing countries on obtaining concessions to facilitate their technological development. ${ }^{107}$ The United States blocked any progress in this respect. $^{108}$

After the provoked failure of the "Patent Harmonisation Treaty ", the Americans tried to include Intellectual Property (IP) in the next round of the General Agreement on Tariffs and Trade, which became known as the GATT 
Uruguay round. ${ }^{109}$ Initially, all developing countries resisted. However, the lobbying of companies in the US and other industrialised countries continued. By making concessions, such as offers for technical assistance to developing countries and introducing transitional periods, eventually, in the mid-nineties agreement was reached.

On 15 April 1995 "The Final Act Embodying the Results of the Uruguay Round of Multilateral Trade Negotiations" was signed in Marrakesh (Morocco). Following this Act, the World Trade Organization (WTO) was founded. ${ }^{110}$ In addition, Annex $1 \mathrm{C}$ of the Act comprised the "Agreement on Trade-Related Aspects of Intellectual Property Rights", better known as the TRIPs agreement. ${ }^{111}$ The Agreement, among others, incorporates by reference the provisions of the Paris Convention on Industrial Property and the Berne Convention on Copyright.

TRIPs is administered by the World Trade Organization (WTO) based in Geneva. The TRIPs Agreement applies to all WTO-members. Today, there are around 165 WTO members. ${ }^{112}$

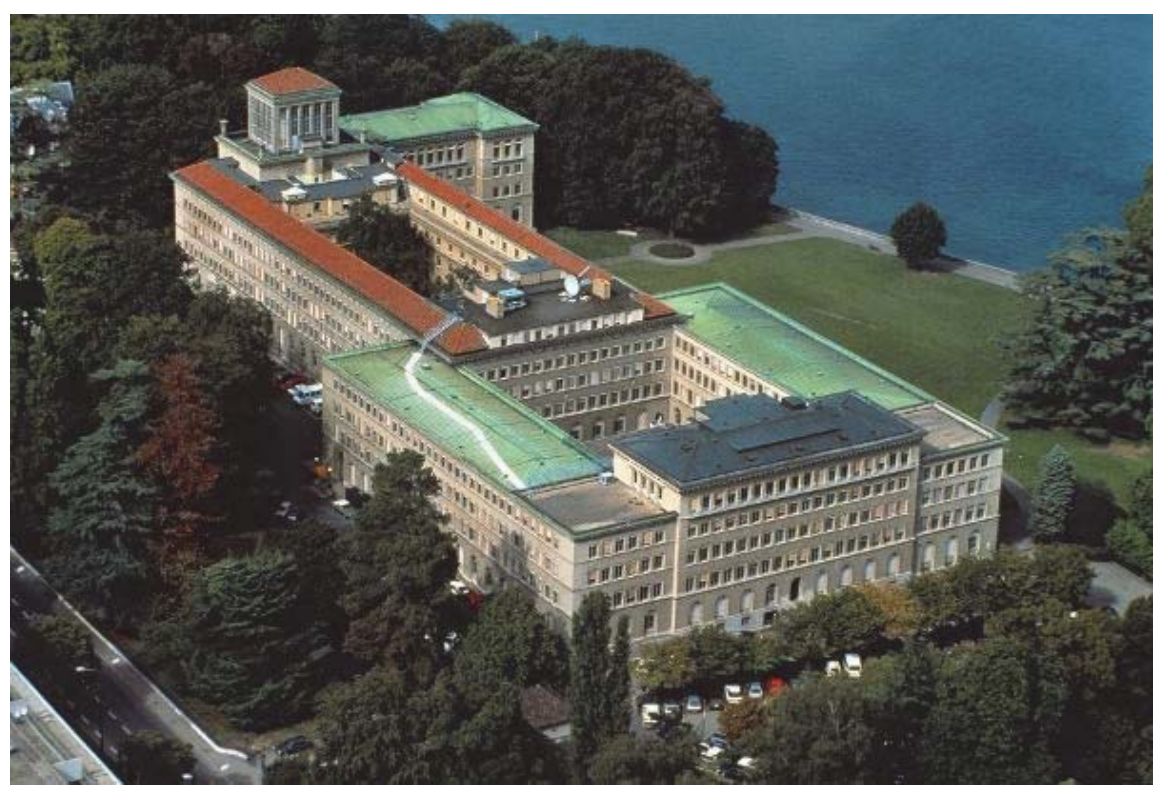

WTO Headquarters (Geneva) 


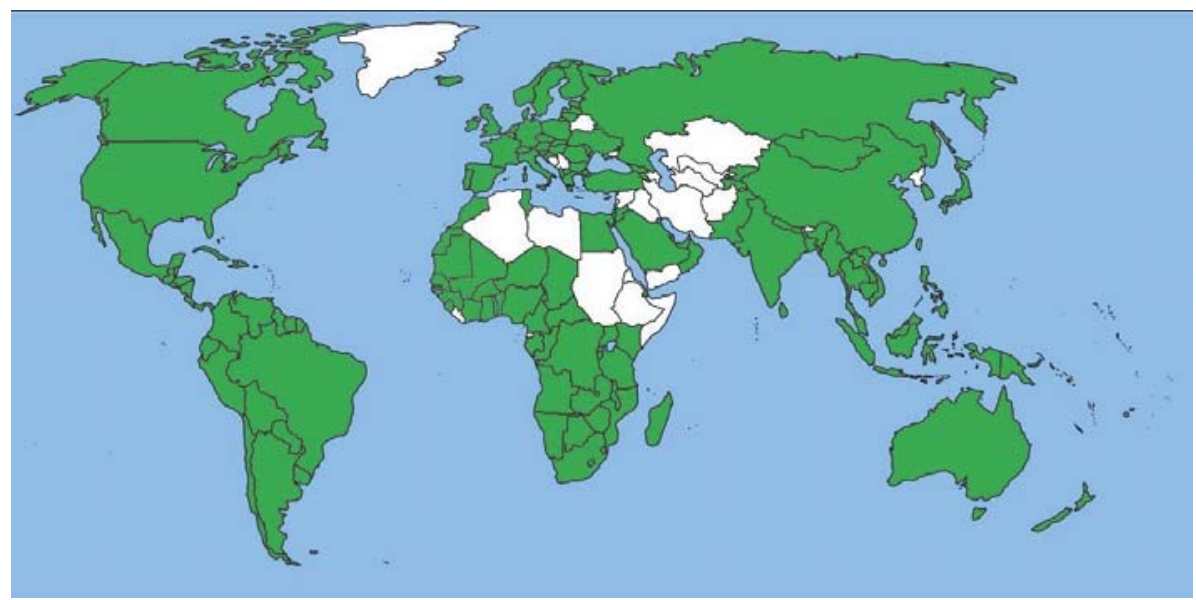

World Trade Organisation - 164 members

It is worth mentioning that many provisions of the Basic Proposal of the Patent Harmonisation Treaty were incorporated in the TRIPs Agreement, such as:

- Definitions of patentable and non-patentable subject-matter; ${ }^{113}$

o Non-discrimination as to field of technology; ${ }^{114}$

- Term of patent protection; ${ }^{115}$ and

- Rights conferred by a patent. ${ }^{116}$

However, vital substantive issues such as novelty and inventive step, were left unresolved in the TRIPs Agreement. In addition, TRIPs fails to provide any protection for traditional knowledge, genetic resources and folklore that are so characteristic of the intellectual wealth of the developing countries. ${ }^{117}$

TRIPs was designed to strengthen and harmonise world-wide intellectual property rights protection. Part I of TRIPs requires member countries to implement and enforce minimum standards for protecting those rights. Part II deals with enforcement of Intellectual Property Rights. Part V deals with dispute settlement, which has become one of the core activities of the World Trade Organisation (WTO).

The TRIPs Agreement also obliges its Contracting Parties to recognise the right of priority for patent applications filed by WTO members, even if these members are not a party to the Paris Convention. ${ }^{118}$ This enabled claiming 
priority from a patent application filed in, for instance, Taiwan because it is a WTO member but not a country party to the Paris Convention. ${ }^{119}$ 


\section{Further attempts to harmonise patent laws}

After the failure of the Patent Harmonisation Treaty and more or less simultaneously with the negations resulting in the TRIPs Agreement, discussions to promote harmonisation of patent laws continued.

\subsection{Patent Law Treaty (2000)}

In the second half of the 1990s, it was agreed that WIPO would initiate another approach for promoting harmonisation, this time by covering only formality requirements of national and regional patent procedures. ${ }^{120}$

During the negotiation process, a number of provisions in the PLT were modelled after texts of Articles already contained in the Basic Proposal for the Patent Harmonisation Treaty. ${ }^{121}$

The resulting Patent Law Treaty (PLT) was concluded during a Diplomatic Conference held at WIPO from 11 May to 2 June 2000. ${ }^{122-123}$ The PLT is open to Paris Convention States and members of WIPO. Currently, the PLT has 39 Contracting Parties. ${ }^{124}$

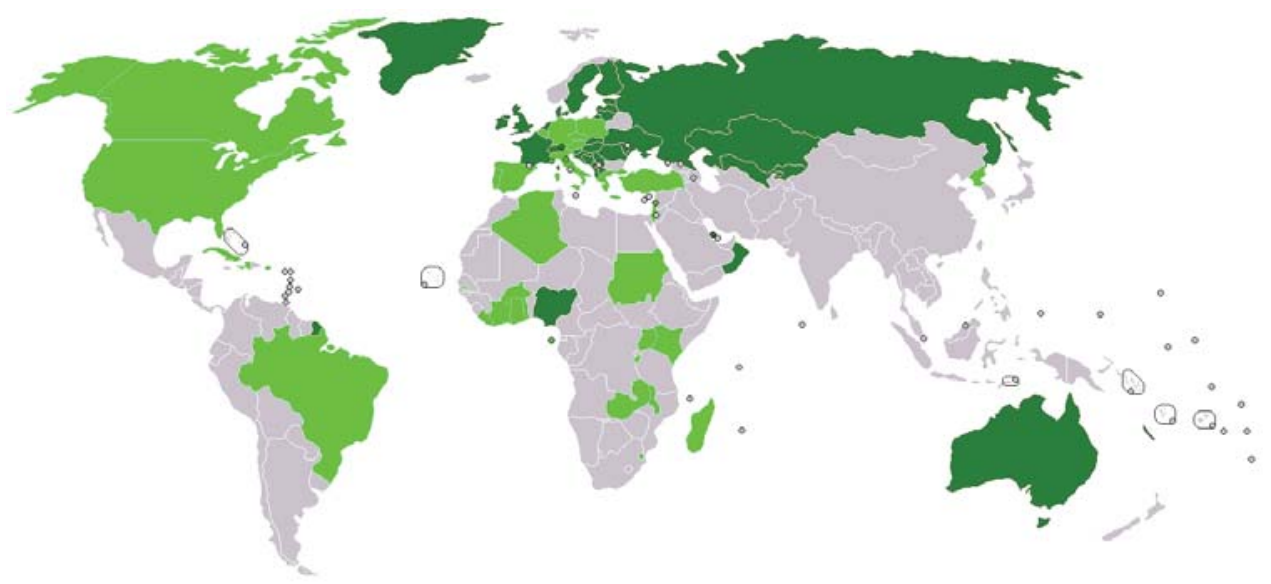

Patent Law Treaty

39 member states and 59 signatory states 
The PLT is also open to certain intergovernmental organizations, such as the European Patent Organization. ${ }^{125}$ During the EPC 2000 revision, the EPC was aligned, in an exemplary manner, with the Patent Law Treaty. ${ }^{126}$ Initially, the European Patent Organisation indicated its desire to become a contracting party to the PLT, but later on this intention was not repeated. ${ }^{127}$

Unfortunately, the Patent Law Treaty did not achieve its goal of 'streamlining and harmonizing' formal requirements. This is caused by the treaty itself, which contains too many optional requirements which may be implemented as compulsory - the so-called 'may require' clauses - by the Contracting Parties.

This allows them too much freedom when implementing requirements of the PLT into their national and regional patent laws. This defies the aim of harmonization and streamlining. ${ }^{128}$

In my opinion, the Patent Law Treaty is a failed treaty. ${ }^{129}$

\subsection{Substantive Patent Law Treaty}

After the conclusion of the Patent Law Treaty, the desire still existed to also harmonise substantive patent requirements, with the ultimate goal to conclude a Substantive Patent Law Treaty (SPLT).

In the period 2000 to 2006 the work progressed in the Standing Committee on the Law of Patents (SCP) established by WIPO. ${ }^{130}$

The aim of a Substantive Patent Law Treaty (SPLT) was to harmonize substantive issues such as requirements for patentability as well as claim drafting, interpretation of claims and enforcement of patents.

In 2004, the United States of America, Japan and the European Patent Office submitted a joint proposal to be presented before the General Assembly of WIPO. ${ }^{131-132}$ 
Among others, the Draft Substantive Patent Law Treaty gave provisions for: ${ }^{133}$

○ Right to patent (inventor, successor in title, employee's inventions); ${ }^{134}$

○ Contents of the application; ${ }^{135}$

○ Unity of invention; ${ }^{136}$

- Opportunity to make observations; amendments or correction of the application and of the patent; ${ }^{137}$

- Prior art; 138

- Information not affecting patentability (grace period); ${ }^{139}$

- Enabling disclosure; ${ }^{140}$

- Contents and style of the claims; ${ }^{141}$

- Conditions of patentability: subject matter eligible for protection; novelty and inventive step; ${ }^{142}$

- Grounds for refusal or a claimed invention; ${ }^{143}$

- Grounds for invalidation or revocation of a claim or a patent; ${ }^{144}$ and

○ Review and Evidence. ${ }^{145}$

It is important to note that the Draft Substantive Patent Law Treaty also is fully integrated with the Patent Law Treaty (PLT) and the Patent Cooperation Treaty (PCT).

During the meeting of the General Assembly of WIPO, consensus could not be reached on the Substantive Patent Law Treaty. The developing countries opposed because in the negotiation process aspects which are fundamental to them had been left aside. ${ }^{146}$

As a result, the negotiations to come to a Substantive Patent Law Treaty were put on hold in 2006..$^{147-148}$

\subsection{More recent developments}

As no progress could be reached via WIPO, other groups have taken up the challenge to promote harmonisation of substantive patent law. A number of initiatives have been developed with the aim to come to a global patent system. 


\section{B+ Group}

The B+ Group - it sounds like a vitamin - was established in 2005. Mainly developed countries work together in this Group. ${ }^{149}$ The B+ Group is assisted by the Industrial Trilateral, which is a group of IP owners in industry from the USA, Europe and Japan.

Discussions in the B+ Group focus on: ${ }^{150-151}$

- Publication of patent applications (18 months);

o Prior art;

○ Conflicting applications;

- Disclosures not affecting the patentability of the invention, including a grace period for inventors; and

- Prior user rights issues (outside of the grace period).

\section{Tegernsee process}

The Tegernsee Group was set up in 2011 and is composed of the heads of offices and experts from the patent offices of Denmark, France, Germany, the United Kingdom, Japan, the United States of America and the European Patent Office (EPO). ${ }^{152}$

Discussions in the Tegernsee process focus on the same issues as the B+ Group. ${ }^{153}$

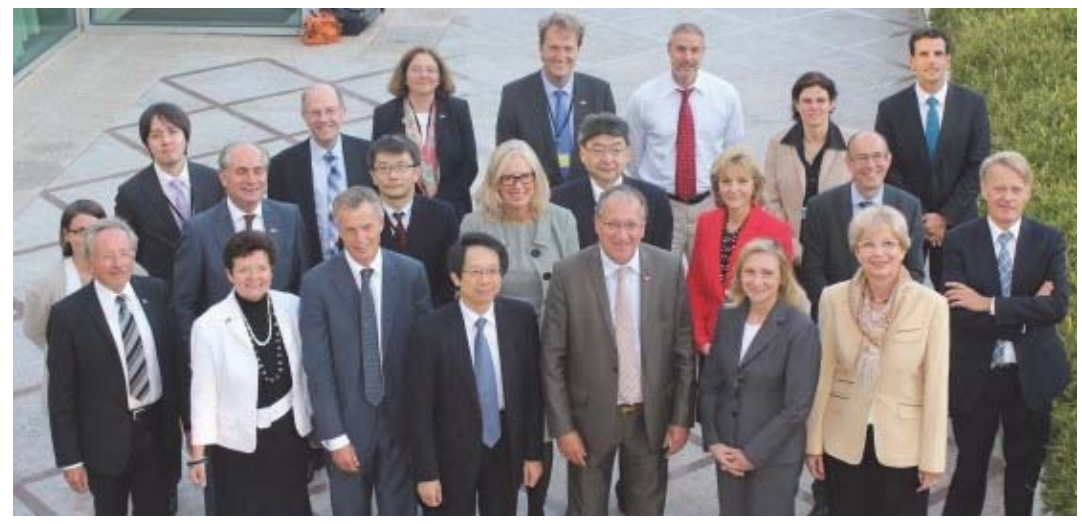

Meeting of the Heads of Patent Offices and representatives from Denmark, France, Germany, Japan, UK, the USA and the EPO (Tegernsee, July 2011) 
The delegations of the Tegernsee Group express their belief in substantive patent law harmonisation, but do not wish to support compromises based on sub-optimal solutions. In particular, there is a reluctance regarding the minimum standards approach. ${ }^{154}$

The developing countries have no voice in these discussions.

\section{Patent Prosecution Highway}

As was mentioned earlier (see $\S 3.2$ ), the Patent Cooperation Treaty (PCT) allows applicants to file a 'single' international application which is searched and published. The PCT does not grant patents: this remains under the control of the national and regional patent Offices in what is called the 'national phase'.

The Patent Prosecution Highway (PPH) is a programme wherein patent offices share information and permits each participating patent office to benefit from the work previously done by another patent office. ${ }^{155}$ The goal is to come to a reduction of the examination workload and to improve the quality of the granted patents.

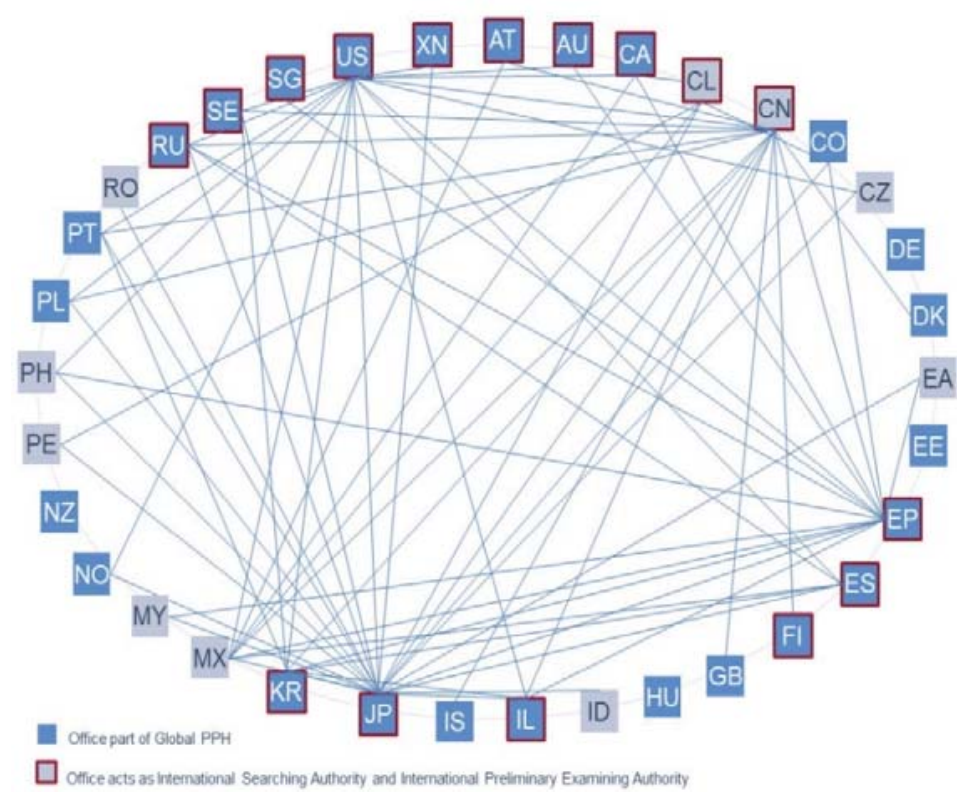

PCT Patent Prosecution Highway Pilot 
Most PPH agreements are bilateral agreements. In 2014, the five largest patent offices agreed to collaborate in the so-called IP5 PPH pilot programme. ${ }^{156-157}$ There also is a Global Patent Prosecution Highway (GPPH) pilot. ${ }^{158}$

A request under the PPH pilot programme can be based on either:

o the latest PCT work product established by one of the patent offices that acted as Searching or Preliminary Examining Authority in the international phase; or

- the national work product established during the processing of a national application or a PCT application that has entered the national phase before the participating offices.

In 2013 attempts were made by the United Kingdom and the United States to integrate the procedural aspects of the Patent Prosecution Highway (PPH) into the Patent Cooperation Treaty. ${ }^{159}$ This would eliminate the need for separate PPH bilateral agreements between patent offices. By reducing duplication of work, this would lead to lower costs for applicants in the trajectory of getting their patents granted at the participating national offices. ${ }^{160}$ In 2014, an updated proposal with a set of opt-out options was submitted. ${ }^{161}$ However, the proposal was not accepted, because of opposition by some BRICS countries. ${ }^{162}$

The result is a web of PPH pilot agreements between patent offices. Each pilot has an end date, at which point it can be decided to extend the pilot or not. ${ }^{163}$ In addition, new bilateral agreements are signed every year. This continuously changing environment makes it difficult for users to develop a strategy for filing and processing their applications. Only when the PPH becomes a more reliable tool, the users may start to systematically incorporate PPH in their patent strategy.

\section{European patent with unitary effect}

I would also like to spend a few words on the advent of the unitary patent and the Unified Patent Court. The inaugural lecture of my colleague Professor Dick van Engelen was devoted to this subject. ${ }^{164}$ 
Unitary Patents will make it possible to get patent protection in up to 26 Member States of the European Union. After grant of the patent by the European Patent Office, the proprietor can file a 'request for unitary effect' for his patent.

In 2012, EU countries and the European Parliament agreed on the 'unitary patent package'. Two EU Regulations were adopted under the umbrella of the so-called 'enhanced cooperation'. ${ }^{165-166}$ In addition, the EU countries agreed to set up a 'single' and specialised Unified Patent Court. ${ }^{167}$

The European Patent Office will be in charge of the registration of the unitary patents as well as collecting and distributing the maintenance fees of the unitary patents. ${ }^{168}$

The unitary patent package can enter into force if it is ratified by at least $13 \mathrm{EU}$ Member States including France, Germany and the United Kingdom. ${ }^{169}$ The outcome of the Brexit referendum in 2016 has made it uncertain that the package will enter into force. In particular, one of the courts of first instance is located in London. Due to a constitutional complaint pending before the German Federal Constitutional Court, the ratification by Germany is also delayed.

The common opinion is that, unless the United Kingdom ratifies the unified patent package before the scheduled departure date of 29 March 2019, the package will not fly. 


\section{Conclusion and outlook}

Allow me to formulate a conclusion.

A truly harmonised patent system with a global unitary patent granted by one central office has been a dream since the conception of the Paris Convention in 1883. And, today, it is further away than ever.

As we have seen, the World Intellectual Property Organisation (WIPO) repeatedly tried to promote patent harmonisation. It never resulted in a Treaty harmonising substantive patent law. Even the Patent Law Treaty with its aim of 'streamlining and harmonizing' formal requirements of patent applications is, as mentioned earlier, a failed treaty. ${ }^{170}$

\section{TRIPs Agreement}

Moving patent issues to the World Trade Organisation (WTO) resulted in the conclusion of the TRIPs Agreement. This Treaty established a new level of harmonisation on a world-wide scale. The larger industrial companies including the pharmaceutical companies benefit most from the TRIPs Agreement.

The TRIPs Agreement only prescribes what one could address as a minimum standard for issues such as the subject matter of patents and the mechanism of enforcement.

The developing countries joined TRIPs as they believed - or were made to believe - that they would no longer 'suffer' from bilateral agreements from the US, Europe and other developed countries. This proved to be an illusion. Socalled TRIPs-plus standards are pushed on developing countries in bilateral and regional agreements. TRIPs-plus standards establish requirements for intellectual property rights that may be much stronger than prescribed by TRIPs. For example, developing counties are forced under TRIPs-plus to provide protection for certain intellectual property rights, whereas TRIPs allows members to exclude such rights. ${ }^{171}$ 


\section{Substantive Patent Law Treaty}

The conception of a Substantive Patent Law Treaty would raise the level of these standards and should also establish a maximum standard which should put restrictions on additional patentability criteria applied by countries. To make things more scary, a Substantive Patent Law Treaty should force governments to abolish their freedom to prescribe their own substantive conditions of patentability.

More harmonisation would simplify the granting process and reduce duplication of the work in the national patent offices. Without a kind of Substantive Patent Law Treaty countries will never be willing to give up part of their autonomy for granting patents.

\section{European Patent Convention}

How 'fit' is the European Patent Convention in relation to patent harmonisation?

The requirement of 'novelty' in the European Patent Convention is believed to be too restrictive. For an invention to lack novelty, a complete conformance of the features of the invention and one prejudicial disclosure is required. ${ }^{172-173}$ The concept of novelty in the EPC has been made so narrow in order to limit the influence of the so-called prior rights. ${ }^{174}$ Prior rights are European patent applications which were filed earlier and published later than the filing of the application whose novelty is contested. ${ }^{175}$

In addition, the European Patent Convention has an Article on non-prejudicial disclosures which only contains two limited exceptions. ${ }^{176-177}$

- One is a 6-month grace period for the display of the invention at an international exhibition - this grace period directly derives from the Paris Convention. ${ }^{178}$

- The other 6-month grace period provides for the situation that an invention was disclosed against the will of the inventor. The boards of appeal of the European Patent Office have interpreted this Article so narrowly, that it has become rather useless for applicants. ${ }^{179}$ 
However, the Article in the EPC on non-prejudicial disclosures does not include a grace period allowing an inventor to file a European patent application within a period of, say, 12 months after disclosing his invention, whereby this disclosure does not affect the patentability of his application.

\section{America Invents Act}

How 'fit' is the US patent law in relation to patent harmonisation?

The 'old' US Patent Act has always been different from the patent laws in the rest of the world. This is a privilege of the largest economy in the world. ${ }^{180}$

Under the Obama administration, the America Invents Act (AIA) was adopted, ${ }^{181}$ which largely aligned the US patent law with the patent laws of other countries. The notorious first-to-invent system was abolished. Among others, a post-grant opposition was introduced. However, the 12-month grace period for inventors was maintained. It allows scientists, researchers and small and medium enterprises to publish first and decide to patent later.

It would seem that by adopting the America Invents Act, the major hurdle for the United States of America for not being able to accept the Patent Harmonisation Treaty of 1991 has been removed. ${ }^{182}$ As was mentioned earlier (see $§ 4.1$ ), this draft Treaty included the first-to-file system as well as a grace period for inventors.

Apart from the USA, a number of countries in the world have adopted a grace period for inventors. ${ }^{183}$

\section{European patent system in a deadlock}

In order to bring forward the harmonisation of patent prosecution around the world, the patent laws of more countries should provide for such a grace period. In particular, the Article on non-prejudicial disclosures in the European Patent Convention (EPC) should be amended to include a 12-month grace period for inventors. As an amendment of an Article in the EPC may take a long time due to the ratification process, ${ }^{184}$ one could consider amending the current wording 'no earlier than six months' in Article 55 EPC to 'no earlier than twelve months'. The Administrative Council of the European Patent 
Organisation is competent to make such an amendment. ${ }^{185}$ At the same time the European Patent Office could broaden the current limited interpretation of the meaning of the wording 'evident abuse' in the Article. There is a decision of the boards of appeal of the European Patent Office that could be employed as a starting point for this broader interpretation. ${ }^{186}$

In my opinion, the current European Patent system is in a deadlock unless the European Patent Office becomes more proactive. At the end of the EPC 2000 Revision Conference, the Chairman Roland Grossenbacher, who at that time was the President of the Administrative Council of the European Patent Organisation, already mentioned that the European Patent Office interprets its role as one of mainly providing a procedural framework concerning patent prosecution. $^{187}$

One of the topics of my research for the forthcoming period will be to come up with a proposal for revising the European Patent Convention.

Among others, proposals for amendment of the Articles of the EPC would include:

- Add a reference in the Preamble of the European Patent Convention to Section 3 of the Vienna Convention of the Law of Treaties in relation to the interpretation of treaties in good faith. ${ }^{188}$

- Remove the boards of appeal from the list of departments of the European Patent Office, making them a third organ of the European Patent Organisation. ${ }^{189}$ This would make the boards of appeal truly independent of the European Patent Office.

- Limit the current three official languages of the European Patent Office to English only. ${ }^{190}$ This will keep Spain on board when revising the European Patent Convention. ${ }^{191}$

- Integrate the search and examining divisions. ${ }^{192}$ In addition, the competences of the search and examining divisions should be merged. ${ }^{193}$

- Delete 'programs for computers' from the list of inventions that cannot be patented. ${ }^{194}$

○ Introduce a 12-month grace period for inventors. ${ }^{195}$ 
- Move away partly from the Patent Law Treaty by requiring that claims are a prerequisite for the accordance of a date of filing. ${ }^{196}$ This would improve harmonisation between the filing date requirements under the European Patent Convention with those of the Patent Cooperation Treaty. ${ }^{197}$

- Add the possibility to review substantive issues to the petition for review by the Enlarged Board of Appeal. ${ }^{198}$ For instance, this would enable the Enlarged Board of Appeal to rectify a wrong decision by a board of appeal about exhaustion of the right to claim priority. ${ }^{199}$

- Improve the definition of 'equivalents' in the Protocol on the interpretation of Art. 69 EPC. ${ }^{200}$ In addition, insert a so-called 'prosecution history estoppel' in this Protocol. ${ }^{201}$ These measures will stimulate harmonisation of proceedings before the patent courts in the Contracting States.

In addition, the Implementing Regulations to the EPC should be simplified. Rarely used Rules should be deleted. ${ }^{202}$ Other Rules, including some historic monstrosities should be reformulated and/or streamlined. ${ }^{203-204}$ Several proposals for amending the Rules have already been published. ${ }^{205-206-207-208-209}$ The result of these and other amendments will reinforce the position of the European Patent Convention as the leading patent treaty in the world. In addition, the European Patent Office could reclaim its position as driving force for patent harmonisation.

While making these amendments, the negations to come to a Treaty Supplementing the Paris Convention as far as Patents are Concerned, which have been suspended since 1991, could be re-opened.

In this manner, patent harmonisation would be promoted.

Europe, the ball is in your court. 


\section{Closing remarks}

At the end of my lecture, I would like to express some words of gratitude. Everything that I did and what I have achieved would have been impossible without the support of many people. A lot of them are sitting here in the audience.

First of all, I am indebted to Prof. Anselm Kamperman Sanders who, in 2009, hired me as a European patent attorney for lecturing half a day per week in the advanced master programme on Intellectual Property Law and Knowledge Management (IPKM) which was about to start. Anselm inspired me to do research for a second $\mathrm{PhD}$, this time on intellectual property law.

I am also grateful to Prof. Dieter Stauder. 20 years ago, I joined the group of tutors in the so-called $D$-seminar organised annually by the Centre d'Etudes Internationales de la Propriété Intellectuelle (CEIPI) in Strasbourg, where, at that time, Dieter was the driving force. Throughout the years, Dieter has inspired me with his friendliness and his attitude of critical thinking. I cherish our friendship.

Of course, I have also learned a lot from my colleagues at the Department of International and European Law of the Faculty of Law in Maastricht. In particular, I would like to mention my colleagues of the IPKM team: Anke Moerland, Ana Ramalho, Meir Pugatch and Dick van Engelen.

Let me not forget to mention the IPKM students who every year come to Maastricht from all over the world. Sometimes, I have to look up the country on the globe to find out where they come from. Teaching you is a privilege. Making new assignments every year is a challenge. Let us hope that your stay in Maastricht has a lasting impact on your professional career.

A special word of thanks for my colleague European patent attorney Nyske Blokhuis: we work together in setting up and giving methodology courses preparing for the European Qualifying Examination to become a European patent attorney. We stimulate each other to be the best tutors for our students. We have become good friends. 
In the audience, I also see many patent attorney colleagues. Allow me to make a small bow for Derk Visser and Joep Van kan.

Some people cannot be here today. My parents died in the period after I defended my first PhD thesis in 1982. I would like to acknowledge them for their love and inspiration. Persons are not dead as long as they are remembered with love.

Of the family of six persons, only my brother and I are still alive. Laus and your wife Fleur and all the kids: let's stick together.

I would also like to mention Geertje Stienstra, who 36 years ago became my 'assistant' in my first job at Philips Research Laboratories. The collaboration resulted in my longest and best friendship; during the years, we have shared so many things.

Present here today are also other good friends. Allow me to mention two: Elly Vogelzang and Ton Kostelijk. I cherish my friendship with you.

Last but not least, special thanks go to my husband Tim van Heijst for his interest, patience and support and also for manufacturing and distributing the books I write. I am so lucky I met him in 1999 and thank him for being the anchor of my life. 
Ladies and Gentlemen,

I have tried to share with you my fascination for intellectual property law, in particular patent law. When I started working at the Philips Patent Department in the early 1990s, the world of patents was still rather dull and patent attorneys were too. The last two decades have shown rapid developments in patent law and in the agility of patent attorneys. Today, the public hears about patent disputes every day. A pity that the world of patents is not better harmonised.

My lecture may have exhausted you. Therefore, it is now time for refreshments.

Ik heb gezegd. 


\section{References}

$1 \quad$ C.A.M. Mulder: "Cooperative phenomena in manganese spin systems at low temperatures", PhD thesis defended on 18 May 1982 at Leiden University.

2 The Big Bang Theory was created by Chuck Lorre and Bill Prady. The first episode was broadcast on 24 September 2007 (CBS).

3 P.W. Anderson: "An approximate quantum theory of the antiferromagnetic ground state", Physical Review 86 (1952) pp.694-701.

4 C.A.M. Mulder, H.W. Capel and J.H.H. Perk: "The Heisenberg Model: Classical ground state and bilinear spin-wave theory", Physica 112B (1982) pp.147-187.

5 C.A.M. Mulder and H.W. Capel: "The Heisenberg Model: Dynamical interactions including odd-boson terms", Physica 115B (1983) pp.310-338.

6 C.A.M. Mulder, H.I. Stipdonk, P.H. Kes, A.J. van Duyneveldt and L.J. de Jongh: "The magnetic phase diagram of the quasi two-dimensional Heisenberg antiferromagnet $K_{2} \mathrm{MnF}_{4}$ ", Physica 113B (1982) pp.380-390.

7 For an up-to-date list of the member countries to the Paris Convention see: www.wipo.int/treaties/en/ShowResults.jsp?treaty_id=2.

8 The World Intellectual Property Organization (WIPO) is a specialized agency of the United Nations. "Agreement between the United Nations and the World Intellectual Property Organization" (December 17, 1974). See: www.wipo.int/treaties/en/agreement/.

$9 \quad$ Georg Bodenhausen (1905-1997) was Director of the United International Bureaux for the Protection of Intellectual Property (BIRPI) from 1963 to 1970, and the first Director General of the World Intellectual Property Organization (WIPO) from 1970 to 1973.

10 G. Bodenhausen: "Guide to the Application of the Paris Convention for the Protection of Industrial Property As Revised at Stockholm in 1967", issued by BIRPI (1969); WIPO Publication N 611 (E). See: www.wipo.int/publications/en/details.jsp?id=239.

11 Art. 2 Paris Convention.

12 Art. 3 Paris Convention.

13 Art. 4A Paris Convention.

14 See endnote 9: Comment (i) in relation to Art. $4 A(1)$.

15 Opinion G 2/98 in relation to the 'same invention' of the Enlarged Board of Appeal of the EPO, Official Journal of the EPO (2001) pp. 413-433.

16 Art. 4A(1) Paris Convention.

17 Art. 4bis Paris Convention. 
18 In the original text of the Paris Convention (1883), the priority period for patents was set at six months. At the Revision Conference in Brussels (1900), this period was extended to become twelve months. Since the Revision Conference in Washington (1911), the 12-month period also applies to utility models.

19 See endnote 9: Comment (i) in relation to Art. 4A(1).

20 Art. 4bis(5) Paris Convention. Note that the common 20-year term of a patent is not mentioned in the Paris Convention.

21 Art. 4ter Paris Convention.

22 Art. 4quater Paris Convention.

23 Art. 5A(1) Paris Convention.

24 Art. 5quater Paris Convention.

25 Art. 5A(2)-(4) Paris Convention.

26 Art. 5bis Paris Convention.

27 Art. 11 Paris Convention.

28 See endnote 9: Chapter II.3; also see footnote 1 on p. 15.

29 Ibid.

30 W. Schuyler: "Paris Convention for the Protection of Industrial Property - A View of the Proposed Revisions", North Carolina Journal of International Law and Commercial Regulation, 8 (1983) pp. 155-166.

31 Convention on the Unification of Certain Points of Substantive Law on Patents for Invention is administered by the Council of Europe. See: http://www.wipo.int/edocs/trtdocs/en/coe/trt_coe.pdf.

32 The Strasbourg Convention has been ratified by 13 Member States of the Council of Europe.

33 Art. 2 Strasbourg Convention.

34 Art. 3 (industrial application), Art. 4 (novelty; grace period) and Art. 5 (inventive step) Strasbourg Convention.

35 Art. 8(2) Strasbourg Convention.

36 Art. 8(3) Strasbourg Convention.

37 Chr. Wadlow: "Strasbourg, the Forgotten Patent Convention, and the Origins of the European Patents Jurisdiction", International Review of Intellectual Property and Competition Law (IIC), 2010 (Vol. 2), pp. 123-149.

38 Articles 52-57 European Patent Convention (EPC).

39 PCT Articles 5-6 and Rule 33.

40 "The first-five years of the Patent Cooperation Treaty (PCT) 1970-1995", WIPO Publication 884 (1995), Chapter I. 
Ibid.

42 The Institut International des Brevets (IIB; International Patent Institute) was an intellectual property organisation established by France, Belgium, Luxembourg and the Netherlands on 6 June 1947 in The Hague.

43 The intention of the drafters of the PCT was that the Institut International des Brevets (IIB) would be the one and only international searching authority under the PCT. This intention is still reflected in PCT Article 16(2) which starts with: "If, pending the establishment of a single International Searching Authority, there are several International Searching Authorities ...".

44 Cf. Art. 6(2), second sentence, EPC.

Also see Official Journal of the EPO (1978) pp. 202-213.

45 In October 2017, the boards of appeal of the European Patent Office were relocated from the Isar Building in München to a building in Haar which is 'eine Gemeinde im Landkreis München'.

46 For an up-to-date list of the international authorities acting as International Searching and International Preliminary Examining Authorities, see: www.wipo.int/pct/en/access/isa_ipea_agreements.html.

47 PCT Art. 21(4) and Rule 48.3. The languages of publication are: Arabic, Chinese, English, French, German, Japanese, Korean, Portuguese, Russian and Spanish. Approximately $50 \%$ of the international applications are published in English (PCT Yearly Review 2018 see endnote 50$)$.

48 PCT Art. 62(1).

49 For an up-to-date list of the States party to the Patent Cooperation Treaty and the Paris Convention and Members of the World Trade Organization, see: www.wipo.int/export/sites/www/pct/en/texts/pdf/pct_paris_wto.pdf.

50 Patent Cooperation Treaty - Yearly Review 2018: The International Patent System, issued by WIPO (2018). See: www.wipo.int/edocs/pubdocs/en/wipo_pub_901_2018.pdf.

51 C. Jewell: "WIPO's PCT publishes 3 millionth international patent application", WIPO Magazine (February 2017). See: www.wipo.int/wipo_magazine/en/.

52 G. Dutfield: "The Limits of Substantive Patent Law Harmonization" in "Patent Law in Global Perspective", Part I, Chapter 5; Editors R.L. Okediji and M. Bagley (Oxford University Press, 2014).

53 C.A.M. Mulder: "The Cross-Referenced Patent Cooperation Treaty" (16 ${ }^{\text {th }}$ edition, helze.com, 2018).

54 PCT Art. 21 and Rule 48.

55 See endnote 50.

56 PCT Rule 48.3(c). 
57 International Preliminary Report on Patentability (Chapter I of the PCT): PCT Art. 35 and Rule 44bis. International Preliminary Report on Patentability (Chapter II of the PCT): PCT Art. 35 and Rule 70.

58 Entry into the national/regional phase before designated Offices: PCT Art. 22 and 23. Entry into the national/regional phase before elected Offices: PCT Art. 39 and 40.

59 PCT Art. 22(1) and 39(1)(a).

60 Art. 64(3) EPC.

61 P. Griset: "The European Patent - A European Success Story for Innovation - Chapter 2: Patents and European Integration", European Patent Office (2013).

62 For an up-to-date list of the participating States to the European Patent Convention and of the current extension States and validation States: see: www.epo.org/about-us/foundation/member-states.html.

63 In the Diplomatic Conference resulting in the EPC 2000 revision, new developments in international law were integrated in the EPC. In particular, the EPC was amended in view of the Agreement on Trade-Related Aspects of Intellectual Property Rights (TRIPs Agreement) and of the Patent Law Treaty (PLT). In addition, a level of judicial review of decisions by the boards of appeal was added.

64 R. Nack and B. Phélip: "Report on the Diplomatic Conference for the Revision of the European Patent Convention" (AIPPI Report, 2000).

65 Art. 53(a) and (b) EPC are derived from Art. 2(a) and (b) of the Strasbourg Convention, whereas Art. 54(1) and (2) EPC are derived from Art. 4(1) and (2) of the Strasbourg Convention.

66 "State of the art" in Guidelines for Examination in the European Patent Office, Part G, Chapter IV. See: www.epo.org/law-practice/legal-texts/guidelines.html.

67 "Synopsis of the territorial field of application of international patent treaties" in Official Journal of the EPO (2012) p. 344.

68 For lists of participating States to the Patent Cooperation Treaty, see: www.wipo.int/pct/en/texts/reg_des.html.

69 For the Lusaka Agreement relating to the creation of the African Regional Intellectual Property Organization (ARIPO), see: www.wipo.int/wipolex/en/other_treaties/details.jsp?group_id=21\&treaty_id=202.

70 For the Bangui Agreement relating to the creation of the Organisation Africaine de la Propriété Intellectuelle (OAPI), see: www.wipo.int/wipolex/en/other_treaties/details.jsp?treaty_id=227.

71 For the Eurasian Patent Convention, see: www.wipo.int/wipolex/en/profile.jsp?code=EAPO.

72 For an up-to-date list of the participating States to the European Patent Convention and of the current extension States and validation States: see: www.epo.org/about-us/foundation/member-states.html. 
73 PCT Art. 45 and Rule 4.9. Also see the Preamble of the European Patent Convention (EPC) and Art. 153 EPC.

74 V. Di Cataldo: "From the European Patent to a Community Patent": Columbia Journal of European Law, 8 (2002), pp. 19-36.

75 "Regulation on the European qualifying examination for professional representatives" and the "Implementing provisions to the Regulation on the European qualifying examination", Rule 26(3). See: Official Journal of the EPO (2017) Suppl. Publication 2.

76 Decision T 24/81 "Metal refining" of the technical boards of Appeal (13 October 1982); Official Journal of the EPO (1983) pp. 133-142.

Another landmark decision is T 2/83 "Simethicone Tablet" (15 March 1984); Official Journal of the EPO (1984) pp. 265-271 ('could-would approach').

77 "Records of the Diplomatic Conference for the Conclusion of a Treaty Supplementing the Paris Convention as far as Patents are Concerned - Volume I: First Part of the Diplomatic Conference - The Hague, 1991", WIPO Publication No. 351(E).

78 See "The Situation Concerning the Patent Law Treaty (PLT)" (memorandum of the International Bureau), Consultative Meeting for the further preparation of the Diplomatic Conference for the Conclusion of the Patent Law Treaty, Document $\mathrm{PLT} / \mathrm{CM} / 2$ (March 1995), Items 4 and 7.

79 Text of the Basic Proposal for the Treaty and Regulations as submitted to the Diplomatic Conference for the Conclusion of a Treaty Supplementing the Paris Convention as far as Patents are Concerned (The Hague 3-28 June 1991), WIPO document SCP/4/3 (2 October 2000). See: www.wipo.int/meetings/en/details.jsp?meeting_id=4203.

80 Notes on the Basic Proposal for the Treaty and Regulations as submitted to the Diplomatic Conference for the Conclusion of a Treaty Supplementing the Paris Convention as far as Patents are Concerned (The Hague 3-28 June 1991), WIPO document SCP/4/4 (2 October 2000).

See: www.wipo.int/meetings/en/details.jsp?meeting_id=4203.

81 Basic Proposal for the Treaty and Regulations as submitted to the Diplomatic Conference for the Conclusion of a Treaty Supplementing the Paris Convention as far as Patents are Concerned: Art. 3.

82 Ibid., Art. 4.

83 Ibid., Art. 5.

84 Ibid., Art. 6 and 9.

85 Ibid., Art. 7.

86 Ibid., Art. 8.

87 Ibid., Art. 10 and 11.

88 Ibid., Art. 12.

89 Ibid., Art. 13. 
Ibid., Art. 14

91 Ibid., Art. 15 and 16.

92 Ibid., Art. 17 and 18.

93 Ibid., Art. 17(2).

94 Ibid., Art. 19.

95 Ibid., Art. 20.

96 Ibid., Art. 21.

97 Ibid., Art. 22.

98 Ibid., Art. 23.

99 Ibid., Art. 24.

100 Ibid., Art. 26.

101 Ibid., Art. 28.

102 Ibid., Art. 30.

103 In the American Invents Act (AIA), the pre-filing grace period is codified in AIA 35 U.S.C. $\S 102(b)(1)(A)$ and (B). See: www.uspto.gov/web/offices/pac/mpep/s2153.html. H. Bardehle: "A New Approach to Worldwide Harmonization of Patent Law", in Journal of the Patent and Trademark Office Society 81 (1999) pp. 303-310. See "The Situation Concerning the Patent Law Treaty (PLT)" (memorandum of the International Bureau), Consultative Meeting for the further preparation of the Diplomatic Conference for the Conclusion of the Patent Law Treaty, Document $\mathrm{PLT} / \mathrm{CM} / 2$ (March 1995), Items 4 and 7. D. Gervais: The TRIPS Agreement, Part A, The Uruguay Round and the Emergence of TRIPS (4 ${ }^{\text {th }}$ Edition; Sweet and Maxwell, 2012).

107 See endnote 30. Ibid., Ch. II "Rule on Unanimity". The GATT Uruguay Round was a series of conferences and meetings held between 1986 and 1994. Also see: www.wto.org/english/thewto_e/whatis_e/tif_e/fact5_e.htm. For the Marrakesh Agreement Establishing the World Tread Organisation, see: www.wto.org/English/docs_e/legal_e/04-wto_e.htm.

111 For the TRIPs-agreement, see: www.wto.org/english/docs_e/legal_e/27-trips.pdf.

112 For a list of States Party to the Patent Cooperation Treaty and the Paris Convention and Members of the World Trade Organization see: www.wipo.int/export/sites/www/pct/en/texts/pdf/pct_paris_wto.pdf.

113 Art. 27 TRIPs agreement.

114 Art. 27.1 TRIPs agreement. 

Economies" in "Patent Law in Global Perspective", Part I, Chapter 2; Editors R.L. Okediji an M. Bagley (Oxford University Press, 2014).

Art. 2.1 TRIPs agreement. WTO members need not ratify the Paris Convention, but they are obliged to comply with Art. 1-12 and 19 of the Paris Convention (1967).

Art. 87(1) EPC regulates that priority can be claimed in or for any State party to the Paris Convention or any Member of the WTO. Also see PCT Art. 8 and Rule 4.10.

"Report" (adopted by the Assembly), Assembly of the International Union for the Protection of Industrial Property (Paris Union), Document P/A/XXII/2 (October 1994).

C.A.M. Mulder: "Patent Law Treaty: Promises Not Delivered - How the Negotiations Resulted in Ambiguities in the Treaty", The Journal of World Intellectual Property 17 (2014) pp. 160-190.

122 Diplomatic Conference for the Adoption of the Patent Law Treaty. See: www.wipo.int/meetings/en/topic.jsp?group_id=136. "Records of the Diplomatic Conference for the Adoption of the Patent Law Treaty (Geneva, 2000)", WIPO Publication No 327(E).

124 For an up-to-date list of the Contracting Parties to the Patent Law Treaty see: www.wipo.int/treaties/en/ShowResults.jsp?lang=en\&treaty_id=4.

125 Art. 20 and Art. 26 Patent Law Treaty.

126 C.A.M. Mulder: "On the Alignment of the European Patent Convention and the Patent Cooperation Treaty with Requirements of the Patent Law Treaty, PhD thesis defended on 19 December 2011 at Maastricht University.

127 C.A.M. Mulder: "Periods and Remedies Under the EPC: Compliance of the EPC with the PLT: Part 1-Extension of Periods and Further Processing", European Intellectual Property Review 34 (2012) pp. 12-21.

The Standing Committee on the Law of Patents (SCP) was created in 1998 to serve as a forum to discuss issues, facilitate coordination and provide guidance concerning the progressive international development of patent law. The SCP is composed of all member states of WIPO and/or the Paris Union. See: www.wipo.int/policy/en/scp/.

131 Meeting documents of the Standing Committee on the Law of Patents, $10^{\text {th }}$ Session, 10-14 May 2004 (Geneva). See:

www.wipo.int/meetings/en/details.jsp?meeting_id=5084. 
Proposal by the USA, Japan and the EPO for establishing a new work plan for the Standing Committee on the Law of Patents (SCP), WIPO General Assembly, Document WO/GA/31/9 (23 July 2004). See:

www.wipo.int/edocs/mdocs/govbody/en/wo_ga_31/wo_ga_31_9.pdf.

Draft Substantive Patent Law Treaty (SPLT), Document SCP/10/2 and SCP/10/4

(30 September 2003). See: www.wipo.int/meetings/en/details.jsp?meeting_id=5084. 
Report of the Discussion - EPO Symposium on Harmonisation Tegernsee and Beyond, European Patent Office (12 February 2015). See: www.epo.org/news-issues/issues/harmonisation/tegernsee-process.html. Regulation 1260/2012" (17 December 2012), Official Journal of the European Union L 361/89. See: eur-lex.europa.eu. 
Unified Patent Court Agreement, Document 16351/12, Council of the European Union (11 January 2013). See register.consilium.europa.eu.

Unitary Patent Guide - Obtaining, maintaining and managing Unitary Patents, $1^{\text {st }}$ edition (August 2017) European Patent Office. See:

www.epo.org/law-practice/unitary/unitary-patent/unitary-patent-guide.html.

For an up-to-date list of the ratification of the Agreement on the Unified Patent Court, see: www.consilium.europa.eu/en/documents-publications/treaties-

agreements/agreement/?id=2013001. See endnote 121.

TRIPS allows members to exclude plants and animals from their patent laws (Art. 27 TRIPs Agreement). However, developing countries in TRIPs-plus bilateral agreements with industrialised countries are being required to provide patent protection on plants and animals. See TRIPS-plus through the back door - How bilateral treaties impose much stronger rules for IPRs on life than the WTO, Grain in cooperation with Sanfec. See: www.grain.org/article/entries/5-trips-plus-through-the-back-door.

Decision T 177/83 "Bayer versus Sportex" of the technical boards of appeal (29 August 1984). See: http://www.epo.org/law-practice/case-law-appeals.

Determining the content of the relevant prior art, Case Law of the Boards of Appeal of the European Patent Office ( $8^{\text {th }}$ edition; 2016) Chapter I.C.4. Ibid., Chapter I.C.4.5.

Art. 54(3) and 153(5) EPC. Also see Guidelines for the Examination in the European Patent Office (2017) G-IV 5. Art. 55 EPC. Also see Guidelines for the Examination in the European Patent Office (2017) G-V. Report on the hearing of 5 October 1998 on a grace period for patents, Official Journal of the EPO (1999) pp.155-165.

Report of the Discussion - EPO Symposium on Harmonisation Tegernsee and Beyond, European Patent Office (12 February 2015). See: www.epo.org/news-issues/issues/harmonisation/tegernsee-process.html. World Economic Outlook Database, issued by the International Monetary Fund. See: www.imf.org/external/pubs/ft/weo/2017/01/weodata/index.aspx.

181 Leahy-Smith America Invents Act (16 September 2011). Public Law 112-29, United States Patent and Trademark Office (USPTO). See: www.uspto.gov/sites/default/files/aia_implementation/20110916-pub-I112-29.pdf.

182 W.G. Barber: Global Patent Harmonization: An Idea Whose Time Has Come, International Review of Intellectual Property and Competition Law, 44 (2013) pp. 1-3. 
Grace Periods for Disclosure of an Invention before Applying for a Patent, Mewburn Ellis LLP (September 2016). See: mewburn.com/wp-content/uploads/2015/04/GracePeriods-for-Disclosure-of-an-Invention.pdf. Perhaps a Revision Conference could be avoided if use would be made of the competence given to the Administrative Council of the European Patent Organisation in Article 33(1)(b) EPC which allows amendment of certain Articles of the EPC "to bring them into line with an international treaty relating to patents or European Community legislation relating to patents" (also see Article 33(5) EPC).

Art. 33(1)(a) EPC gives the Administrative Council competence to amend the time limits laid down in the European Patent Convention.

Decision T 173/83 "Antioxydans" of the technical boards of appeal (1 July 1985). See: www.epo.org/law-practice/case-law-appeals.

187 Conference Proceedings of the Conference of the Contracting States to Revise the 1973 European Patent Convention (Munich, 20-29 November 2000) Document MR/24/00 (15.07.2003). See: www.epo.org/law-practice/legaltexts/epc/archive/documentation/diplomatic-conference.html. Art. 31-33 of the Vienna Convention on the Law of Treaties (23 May 1969) United Nations Treaty Series Vol. 1155 (1980) pp. 331-353.

189 Currently, the boards of appeal and the Enlarged Board of Appeal are departments of the EPO: see Art. 15(f) and (g) EPC. They should become 'Organs' of the European Patent Organisation under Art. 4(2) EPC. Currently, the official languages of the EPO are English, French and German (Art. 14(1) EPC). At earlier occasions, Spain has indicated that Spanish should become an official language of the EPO. Spain has also indicated it would be acceptable if English would be the only official language of the EPO. One of the reasons why Spain refused to join the unitary patent and the Unified Patent Court is that Spanish is not one of the official languages of the EPO.

192 The competences of the search divisions (Art. 15(b) and 17 EPC) and examining divisions (Art. 15(c) and 18 EPC) should be merged into one Article.

193 The drawing up of the European search report including the search opinion (Art. 92 and Rule 62 EPC) and the substantive examination of the European Patent application (Art. 94 EPC) should be integrated. 
The removal of programs for computers from Art. 52(2)(c) was discussed during the EPC 2000 Revision Conference with the view that it had become obsolete in view of the existing EPO practice. See: Conference Proceedings of the Conference of the Contracting States to Revise the 1973 European Patent Convention (Munich, 20-29 November 2000) Document MR/24/00 (15.07.2003). See: www.epo.org/law-practice/legaltexts/epc/archive/documentation/diplomatic-conference.html. Also see Opinion G 3/08 in relation to "patentability of programs for computers" of the Enlarged Board of Appeal of the EPO (12 May 2010):, Official Journal EPO (2011) pp. 10-59.

Currently, the non-prejudicial disclosures in Art. 55 EPC only encompass: a 6-month grace period for the situation that an invention was disclosed against the will of the inventor (Art. 55(1)(a) EPC) and a 6-month grace period for display of the invention at an international exhibition (Art. 55(1)(b) and Rule 25 EPC).

Currently, claims are not required for the accordance of a date of filing of a European patent application (Art. 80 and Rule 40(1) EPC). This is in line with Art. 5(1) of the Patent Law Treaty.

One of the requirements for the accordance of the international filing date, is that the international application should contain "a part which on the face of it appears to be a claim or claims." (PCT Art. 11(1)(iii)(e)).

Article 112a EPC was introduced during the EPC 2000 Revision Conference. It provides a limited judicial review of decisions of the boards of appeal. The petition may only be filed on the grounds as listed in Article 112a(2) EPC. In addition, the petition for review has no suspensive effect (Article 112a(3) EPC).

In decision T 998/99 "Skin equivalent versus L'Oreal" of the technical boards of appeal (15 September 2003), it was held not allowable to claim the same priority for the same subject-matter in respect of several European patent applications.

In decision T 15/01 "Mystery swine disease" of the technical boards of appeal (17 June 2004), the common practice of the EPO to allow claiming the same priority right in more than one European patent application was endorsed.

See: http://www.epo.org/law-practice/case-law-appeals.

200 In preparation of the EPC 2000 Revision Conference, a proposal for amending the Protocol on the Interpretation of Art. 69 EPC was considered, which included a good and workable definition of 'equivalents' (Art. 2). Document CA/PL 25/00 Add. 2 (5 July 2000). See www.epo.org/law-practice/legal-texts/epc/archive/documentation/travauxpreparatoires/plc-documents.html.

Eventually, a very limited text was accepted during the Revision Conference. 
In preparation of the EPC 2000 Revision Conference, a proposal for amending the Protocol on the Interpretation of Art. 69 EPC was considered, which included a prosecution history estoppel (Art. 3 entitled 'prior statements'). Document CA/PL 25/00 Add. 2 (5 July 2000).

See www.epo.org/law-practice/legal-texts/epc/archive/documentation/travauxpreparatoires/plc-documents.html.

Eventually, the including an article in the Protocol in relation to the prosecution history estoppel was not accepted during the Revision Conference.

Implementing Regulations to the EPC which could be deleted are:

- The ten-day rule for notification of documents by postal services (Rule 126(2) EPC) and by means of electronic communication (Rule 127(2) EPC).

- Late receipt of documents (Rule 133 EPC).

Implementing Regulations to the EPC which should be amended are:

- Clarify that amendments to the European patent application can also be filed in an official language of a Contracting State by an entitled person (Rule 3(2) EPC).

- Remove the requirement from Rule 40 EPC that a translation of the previously filed application must be filed where that application is not in an official language of the EPO (Rule 40(3) EPC). This requirement has no influence on the accordance of the date of filing.

- Introduce a legal basis for the payment of the extension fees and validation fees and streamline the payment with that of the designation fee. This could be effected by adding an extra paragraph to Rule 39 EPC. At the same time, the title of Rule 39 EPC should be brought into conformity with the abolishment of multiple designation fees which entered into force on 1 April 2009.

- Align the payment of claims fees (Rule 45 EPC) with that of the filing and search fee (Rule $38 \mathrm{EPC}$ ).

- Simplify and streamline the payment of renewal fees (Rule 51(1) EPC): make the payment of a renewal fee the result of the expiry of a time limit.

- Indicate the sanction when not complying with a request for correction in relation to the accordance of the date of filing (Rule $55 \mathrm{EPC}$ ). Currently, the sanction is only in the Guidelines for Examination in the EPO.

- Require, when filing missing parts of the description and missing drawings based on an earlier application, that the priority claim has to be made when filing the application (Rule $56 \mathrm{EPC}$ ). This is a mandatory requirement according to the Patent Law Treaty (Art. 5(6)(b) PLT); it is also a compulsory requirement in the PCT (PCT Rules 4.18 and 20.5 and 20.6).

- Introduce the interlocutory decision in Rule 89(2) EPC, which decision becomes final if none of the parties to the opposition proceedings files an appeal.

- Prescribe that upon filing amendments to the European patent, the identification and indication of the basis of the amendments in the application as filed (Rule 137(4) EPC) are also applicable in opposition proceedings. This could be implemented by adding a 'mutatis mutandis' reference to Rule 137(4) EPC in Rule 86 EPC. 
204 Implementing Regulations to the EPC in relation to Euro-PCT applications which should be amended are:

- Refer to the respective fees for the EPO acting as International Searching Authority (ISA) or International Preliminary Examining Authority (IPEA) in the international phase (Rule $158 \mathrm{EPC})$.

- Simplify the amendment of the Euro-PCT application after entry into the regional phase before the EPO (Rule $161 \mathrm{EPC}$ ).

- Harmonise the requirements for further searches and non-unity in relation to Euro-PCT applications independent of whether the EPO acted as ISA in the international phase (Rule $164 \mathrm{EPC}$ ).

205 C.A.M. Mulder and D. Visser: Filing date requirements under the EPC - filing by reference to a previously filed application, epi Information 04|2010 pp. 126-129.

C.A.M. Mulder and D. Visser: Proposals for Streamlining the Filing Date Requirements of the European Patent Convention, International Review of Intellectual Property and Competition Law (IIC), 44 (2013) pp. 220-230.

207 C.A.M. Mulder: Proposal for Simplifying and Streamlining the Payment of Renewal Fees in the European Patent Convention, European Intellectual Property Review 37 (2015) pp. 644-652.

C.A.M. Mulder: Amendment of Rule 51(2) EPC relating to the payment of renewal fees in the 6 month additional period and its consequences, epi Information 02|2017 pp. 20-23. applications after entry into the regional phase before the European Patent Office, accepted for publication in European Intellectual Property Review. 